\title{
Market Multiples and the Valuation of Cyclical Companies
}

\author{
Emanuel Bagna ${ }^{1}$, Enrico Cotta Ramusino ${ }^{1}$ \\ ${ }^{1}$ Pavia University, Italy \\ Correspondence: Emanuel Bagna, Pavia University, Italy
}

Received: September 15, 2017

Accepted: November 14, 2017 Online Published: November 23, 2017

doi:10.5539/ibr.v10n12p246

URL: https://doi.org/10.5539/ibr.v10n12p246

\begin{abstract}
Market multiples are more often used than studied. Equity analysts, investment bankers and other practitioners widely use market multiples to estimate the value of companies. Nevertheless, literature about multiples is not as rich as the wide use of these valuation tools would suggest. This paper, focusing on European listed companies, investigates how multiples can be used in the valuation of cyclical companies, a much less investigated research topic. We test the accuracy of multiples to understand whether their performance in valuing cyclical companies is better, worse or equal to the performance found in prior studies, where both cyclical and non cyclical companies are analyzed without distinguishing between them. We also attempt to verify whether the way in which multiples are calculated significantly affects the accuracy of estimation. Our aim is to develop a valuation approach consistent with valuation theory and helpful in everyday practice.
\end{abstract}

Keywords: valutation, valuation multiple, cyclical companies

JEL classification: G32, G12, G30

\section{Introduction and Purpose of the Paper}

In practice - in equity research, mergers and acquisitions, IPOs, etc.- multiples ${ }^{1}$ are widely used to estimate the value of companies and this is basically due to three main reasons. First of all, a wealth of information is available to support the methodology, at least in its quick and dirty form. Secondly, multiples link to market prices and the idea of a fair value approach. Third, no one pretends, at least when using its simplest form for multiples valuation, to be accurately estimating future earnings, cash flows, growth rate or cost of capital.

Notwithstanding their practical relevance, multiples have been analyzed in a limited number of academic studies, so that, in this particular field, practice tends to prevail on theory.

Valuation through multiples is carried out in three basic steps. First comes the choice of the multiple (or multiples, if the valuator uses more than one to increase the accuracy of the estimation) on which to base the valuation. Second is the selection of a sample of comparables. And third is the calculation of the multiple(s) itself. Finally, the value of the target company is estimated by multiplying the multiple(s) for the economic or financial driver of the target.

The choice of the multiple(s) is often made on a judgmental basis, with each person using the multiple(s) that is (are) more often used by others in similar situations. ${ }^{2}$

The selection of comparables is commonly made according to industry criterion. Equity analysts, for example, will group companies belonging to the same industry or operating in the same or in similar markets ${ }^{3}$ and

\footnotetext{
${ }^{1}$ Accordingly to Pinto, Henry, Robinson, \& Stowe (2010) 'Price multiples are ratios of a stock' s market price to some measure of fundamental value per share" while "Enterprise value multiples, by contrast, relate the total market value of all sources of a company 's capital to a measure of fundamental value for the entire company".

${ }^{2}$ Price-to-earnings ratio (PE); or price-to-book value (PB) for financials; enterprise value (EV) to earnings before interest, taxes depreciation and amortization, (EBITDA); enterprise value to earnings before interest and taxes (EBIT); enterprise value to sales (S) or enterprise value to net invested capital (IC) for industrial companies, etc.

${ }^{3}$ In the case that an industry is segmented in different areas showing different trends, we find that practitioners often conduct the analysis making reference to regions (e.g. the EV/EBITDA multiple of European steel companies or the PB multiple of European banks). When the industry is global, the sample must be built accordingly.
} 
calculate multiples on the basis of these samples. Similarly, investment bankers advising firms going public determine offering prices by making reference to listed industry peers. In both cases, the comparison generally accounts for firms with similar fundamental features, ${ }^{4}$ implicitly acknowledging their impact on the level of the multiples used for valuation purposes.

Multiples applied to a target company may be calculated in different ways. The most common practice is to assume direct proportionality between the multiple and the value driver, so using the average or median multiple to multiply the target's economic or financial driver.

The valuation of cyclical companies is an even less investigated research topic, despite its relevance from a practical point of view, as these firms represent an important segment of the economy, and analysts, bankers, and practitioners have to deal every day with valuing both listed or private cyclical firms. According to some contributions coming mainly from textbooks, a common approach among professional is that, in the calculation of the value of these firms, average cycle performance must be taken into account, being point in time results not able to express the real 'average' capacity of the firm to produce earnings or cash flows.

Given these premises, our paper aims at filling a gap in literature, providing at the same time a useful contribution to professionals engaged in cyclical companies valuation. In particular, we want to give an answer to three research questions:

1) May multiples be used in the valuation of cyclical companies achieving a le vel of accuracy comparable to that found in prior studies, where both cyclical and non cyclical companies have been considered, without distinguishing between them?

2) Does the way in which multiples are calculated matter?

3) Is it necessary, in the case of cyclical companies, to focus on medium term average performances?

The paper proceeds as follows. Section 2 reviews the literature. Section 3 illustrates our theoretical framework and the structure of the empirical analysis. Section 4 presents our main findings. Section 5 concludes.

\section{Literature Review}

Multiples are analyzed in a limited number of studies, many of which dated. In general, the aim of existing studies is to compare multiples in order to find those providing the best estimation accuracy, without distinguishing between cyclical and non cyclical firms. In table 1, we report the main features of a number of relevant research works that investigated this topic; for each, we highlight objectives, methodology and main findings. As one can see from the table, the contributions differ significantly on several dimensions - the purpose of analysis, the number of firms examined, the criteria for peer selection, the way in which multiples were calculated, the main findings. We found that results were often controversial, at least regarding some of the aspects of the methodology. As far as accuracy, different authors reached quite different results, while on the side of peer selection, the industry criterion is almost unanimously considered the proper choice, at least as a first step; the possibility of improving the effectiveness of this criterion by considering additional ones (like profitability, growth, risk and size) is often broached, ${ }^{5}$ even if there is not agreement about effects on estimation accuracy. As far as calculation methodology is concerned, again, approaches differ. While in the practice of financial markets average/median multiples are often assumed as a benchmark for valuations, the literature also examines the use of the harmonic mean and regression analysis. Different authors find that the latter methods do not always produce improvements in valuation results.

The research gap is even much more evident in the case of cyclical companies, particularly for what concerns the application to them of the relative valuation methodology.

We found contributions on this topic mainly in textbooks dealing with valuation and in a limited number of research papers. ${ }^{6}$ Some major points are common in discussions. First, some authors point out that valuing cyclical companies is more difficult than valuing noncyclical ones. De Heer, Koller, Schauten, \& Steenbeck (2000) hold that the valuation of cyclical companies is more complicated compared to noncyclicals because, at any point in time, it is difficult to state whether the current cycle will continue. They observe that earnings

\footnotetext{
${ }^{4}$ Market in which the firm operates, business model, actual and future profitability, risk, growth perspectives.

${ }^{5}$ Among studies not examined in Table 1, Dittman and Weiner (2005), in a research focused on European companies, show how selecting comparables according to the return on assets leads to the best results in terms of accuracy, when using EV/EBIT as estimator.

${ }^{6}$ Often working papers, not published in major financial journals.
} 
forecasts are particularly poor in the case of cyclical companies as financial analysts seem to ignore cyclicality, overvaluing companies at the peak of the cycle and undervaluing them at the bottom (with overvaluation being, in absolute terms, greater than undervaluation). Koller, Goedhart, \& Wessels (2005), for example, observe that the valuation of cyclical companies represents a field in which theory and reality conflict: share prices of cyclical companies, according to authors, fluctuate more than those of noncyclical ones and, above all, fluctuate more than one would expect on the basis of a discounted cash flow (DCF) valuation. Tremolizzo (2009) finds that applying multiples to cyclical companies leads to valuation errors that are greater than in the case of noncyclical firms.

A second issue on which some authors focus is how to deal with cyclicality in earnings for valuation purposes. In cyclical companies, current profitability or cash flow indicators may, at a given point in time, not represent the average conditions of the firm. Profitability and cash flow are normally depressed at the bottom of the cycle and high at the peak. This variability of economic results is managed, in practice, according to the principle of normalized earnings (operating or net), which tries to identify the normal (average) profitability potential of the company over the whole cycle. The principle of averaging results is the basic option, with different adjustments. Examples of this approach may be found in work by Damodaran $(2009,2012)$ and by Pinto, Henry, Robinson, \& Stowe (2010), where the suggested approach is to consider historical results. As an adjustment, Pinto et al. (2010) consider the possibility of using the average profitability ratio, instead of earnings, when the firm has had a significant increase of invested capital. Koller et al. (2005) also suggest considering past results to understand the real profitability potential of a company and to combine this analysis with a forward-looking estimate of a future possible break in the cycle. Their approach is to consider several scenarios-a base one in which the company is supposed to behave in the future as it has in the past and another one considering the possibility of cycle break - and to weight these scenarios according to their likelihood. The probability is estimated by considering the rationality of both hypotheses. Note that the idea of averaging results over the cycle is not correlated with the use of multiples. To the contrary, authors who hold to the principle of averaging results also consider fundamental methodologies, like discounting earnings or cash flows. Among these just mentioned contributions, the only one applying the idea of average cycle performance in relative valuation is the one of Damodaran. In conclusion, the idea of averaging (normalizing) economic and financial results in order to get the normal cycle performance, seems to be a very common idea for the purpose of valuing cyclical companies.

\section{Research Structure}

\subsection{The Sample}

Our analysis covers the 2003 - 2012 decade. We have extracted from the Factset database a sample of European companies by using the following procedure. First we selected, with reference at the date of 07/01/2013, all listed companies within the European Union, Norway, and Switzerland (in total, 29 countries) with a sector classification within Dow Jones Industry Classification Benchmark (ICB). ${ }^{7}$ According to this system, firms are classified in 10 industries, partitioned into 18 sectors. ${ }^{8}$ We have assumed a company as cyclical, consistent with financial market practice, if it is classified into the following three industries (eight sectors): Basic Materials ([1] Basic Resources, [2] Chemicals), Consumer Cyclical ([3] Automobiles, [4] Cyclical Goods and Services, [5] Media, [6] Retail), and Industrial ([14] Construction, [15] Industrial Goods and Services). Our approach resembles Morningstar's industry classification, ${ }^{9}$ with two differences. The first is that we exclude from the sample financial companies, that, due to the impact of the recent financial crisis, could have had a relevant

\footnotetext{
${ }^{7}$ The Dow Jones Industry Classification Benchmark (ICB) is an taxonomy launched by Dow Jones and FTSE in 2005 and now owned solely by FTSE International.

${ }^{8}$ To identify cyclical companies, we relied on the ICB (old version of the classification) available in the Factset database at the date of extraction of our sample. This classification distinguishes among the following industries [sectors]: 1) Basic Materials ([1] Basic Resources, [2] Chemicals); 2) Consumer Cyclical ([3] Automobiles, [4] Cyclical Goods and Services, [5] Media, [6] Retail); 3) Consumer Noncyclical ([7] Food \& Beverage, [8] Noncyclical Goods \& Services); 4) Energy ([9] Energy); 5) Financial ([10] Banks, [11] Financial Services, [12] Insurance); 6) Healthcare ([13] Healthcare); 7) Industrial ([14] Construction, [15] Industrial Goods and Services); 8) Technology ([16] Technology); 9) Telecommunications ([17] Telecommunication); 10) Utilities ([18] Utilities). The ICB has recently been changed, removing the distinction between cyclical and noncyclical goods. The old version is still available on Factset database, and we decided to rely on it as it better fits the purpose our study.
}

${ }^{9}$ See Morningstar, Morningstar Global Equity Classification Structure, Morningstar Research, May 24, 2011. 
impact on results. Another reason for excluding financials is that we use asset-side multiples in our valuations, which are generally considered less appropriate in the case of these companies. The second difference is that we include industrial companies in our sample, while Morningstar classifies them in the supersector, denominated "sensitive," that lies between cyclical and defensive. Given the lack of a universal definition of "cyclical companies," we are convinced that our selection criteria can be considered a sensible basis for empirical analysis.

The whole sample is comprised of 1933 companies (table 2). As a second step of our procedure, we trim our sample, eliminating all the observations below the fifth and above the ninety-fifth percentile. We also drop all the observations with negative values of EBIT and EBITDA. Finally, we consider only those companies for whom all data are available in a given year. ${ }^{10}$ As a consequence, the number of firms has been significantly reduced compared to the initial number. Our sample is comprised of about 800 firms per year, for a total of 7,844 firm/year observations.

\subsection{Methodology}

\subsubsection{Which Multiple?}

The literature does not reach unanimous conclusions about the best multiple or multiples to use in valuations. Our approach follows an idea first signaled by Kaplan and Ruback (1995 and 1996) and then by Pratt (2001) ${ }^{11}$, but actually not applied in subsequent research studies. The idea is to select, among possible multiples, the one(s) that show the minimum variability ${ }^{12}$ over a given period, in order to be confident that through this choice we are basing the valuation on economic or financial drivers (the basis of the multiple) that really matter for the market. Even when more than one multiple is used in the valuation, the selection of the multiple may be made on the basis of minimum variability, and the weights may be determined according to parameters stemming from empirical analysis ${ }^{13}$.

For this reason we previously submitted a list of seven multiples, the most widely used in practice, to a check through dispersion analysis, over the period 2003 -2012: results are reported in table 3. The coefficient of variation - the measure of dispersion - is calculated for each company as the ratio between the standard deviation and the average over the 10-year period and the cross-sectional average is the coefficient of variation for each multiple. Dispersion analysis suggests that asset-side multiples, which are significantly less disperse than equity side multiples, may provide better estimates. Given these first empirical findings, we have decided to carry out our analysis using asset-side multiples only, and we note that this approach is consistent with market practice, as analysts, bankers and other practitioners do their valuations mainly using asset-side multiples.

\subsubsection{Peer Selection}

We use the "industry criterion" for picking peers, using firms from the same sector within a given industry, thus accepting a common approach in both the literature and practice. When valuing companies through this methodology, practitioners generally refer to comparable firms belonging to the same industry. As we calculate multiples (even) through regression analysis, we are confident that we can also capture what some authors search for, specifically, basing the selection of comparables on similarity of fundamentals. In this way, we account for the other main methodological alternative that can be found in the literature.

\subsubsection{Multiple Calculation}

We consider only current multiples, as the use of forward ones would significantly reduce the number of firms in our sample. The numerator is the EV at the end of the year, and the denominator is the value of the economic

\footnotetext{
${ }^{10}$ For each company, the following data were considered necessary to be included in the sample: positive EBIT and EBITDA (either current and the two- to four-year average), invested capital, sales.

${ }^{11}$ See Kaplan and Ruback (1996), p. 48: "Valuation by comparables or multiples relies on two assumptions. First, the comparable companies are assumed to have expected future cash flows that grow at the same rate and have the same level of risk as those of the firm being valued. Second, the value of the company is assumed to vary in direct proportion with changes in the performance measure; that is, if expected EBITDA increases by $10 \%$, expected value also rises by 10\%.” The same concept may be found in Pratt (2001), p. 133.

${ }^{12}$ As measured by the ratio between standard deviation and average of the multiple, over a given period.

${ }^{13}$ As an example, if we calculate multiples through regression analysis, the weights of the multiple may be determined according to the results obtained through the regressions themselves (for example weighting multiples on the basis of the R squared (adjusted) of the regressions used to calculate them).
} 
quantity at fiscal year-end. We also address the concern raised by some authors that, when dealing with cyclical firms, hold that valuation should consider average cycle performance. As a consequence, we base our valuations on average (cycle) results. As we already pointed out, this approach is normally associated with fundamental valuation methodologies, based on earnings or cash flow discounting. In our case, focusing on valuation multiples, we want to check whether the idea of averaging results improves estimation accuracy. We will then calculate both current and historical multiples, the latter obtained by putting in the denominator the average of the income statement drivers (EBIT, EBITDA, SALES) over a period of two to four years. ${ }^{14}$ We intend to verify whether averaging economic results can help to obtain better estimations even if, from an economic perspective, one would expect that multiples, being based on market prices, should already include investors' valuation of the average performance of cyclical firms. Market prices, the numerator of the multiples, should then, at least in theory, be sufficient to consider the specific features of cyclical firms, and averaging economic results should not prove relevant for estimation accuracy. We average only income statement drivers as balance sheet ones (in our case, invested capital) are less subject to cycle dynamics. For this reason, we will have, in the case of multiples based on income statement drivers, four values instead of one.

Given these multiples, we first determine, according to the principle of direct proportionality, the average, the median, and the harmonic mean and use these benchmarks multiple to evaluate each company in the sample. Considering these three estimators, we take into account what is done by all authors analyzed in our literature review. The direct proportionality approach is based on the assumption that companies will converge to average sector conditions. If this holds true, multiplying the benchmark ${ }^{15}$ sector multiple by the basis of the multiple (the denominator) of the target company, may be considered a sound estimation approach

When the denominator of the multiple is represented by a measure of income (both operating or net), the underlying hypothesis of convergence to the mean multiple holds when risk profiles and growth prospects are equal for all the companies in the sample ${ }^{16}$.

When the denominator of the multiple is represented by a measure of capital (net invested capital or common equity) or revenues, the underlying hypothesis of convergence is true when risk profiles, growth prospects, and profitability are the same for each company. The reason is immediately obvious: any revenues / invested capital multiple can be clearly decomposed into the product of the primary multiple (Enterprise Value / Unlevered Free Cash Flows $\mathrm{t}_{\mathrm{t}=1}$ ) and the profitability of the specific company being valued.

The limits of the application of sector mean multiples are so rooted in the differences in terms of risk, growth prospects, and profitability among companies included in the sample. These limitations can be overcome with the use of different estimators, namely OLS, by introducing regressions. Regressions can explain the cross-sectional dispersion among different multiples on the basis of fundamental drivers. For instance, if one were to use the multiple Enterprise Value / Invested Capital, it is possible to use, as independent variable, some measures of profitability, growth, or risk. The greatest advantage of a regression is, however, pointed out by Liu, Nissim, \& Thomas (2002), that is, the introduction of the intercept $\alpha$, which can capture the effects of omitted variables in the valuation model. By introducing an intercept, one should be able to capture the fundamental elements common to all firms (in terms of growth, risk and profitability).

Based on these considerations, we decided to calculate multiples through single-factor regressions, using fundamental drivers as independent variables and allowing for an intercept with the purpose of capturing the impact of omitted variables. The identification of independent variables to be used in the regression analysis is made by leveraging on a simplified model of fundamental analysis.

From the fundamental model, we have calculated EV/S and EV/IC through a single-factor regression where the multiples are the dependent variables and the independent ones are EBIT/S and EBITDA/S in the first case and EBIT/IC and EBITDA/IC in the second.

\footnotetext{
${ }^{14}$ In our analysis, we have even calculated average results over a longer period, up to eight years, but we do not show these data as we verified that extending the period does not contribute to estimation accuracy.

${ }^{15}$ We use in the text the term "mean" multiple but the same holds in the case of multiples calculated through median or harmonic mean.

${ }^{16}$ To understand the reasons, it is sufficient to decompose the multiple Enterprise Value / NOPAT into its fundamental determinants. The value of assets of a company can be expressed by a synthetic Discounted Cash Flow Model, by capitalizing the current Unlevered Free Cash Flows $\left(\mathrm{UFCF}_{\mathrm{t}=1}\right)$ at a rate that equals the difference between the opportunity cost of capital (the weighted average cost of capital, wacc) and the growth rate $(\mathrm{g})$.
} 
We decided not to include, among independent variables, (1) the weighted average cost of capital (wacc), basing this decision on the hypothesis of a common industry level, ${ }^{17}$ and (2) the corporate tax coefficient (Tc), given the wide range of values of this driver among different countries and its numerous changes in the course of time. We also assumed that the value of the growth rate (g) depends both on the industry perspective (a fraction of it that may be considered uniform among companies) and on firm specific conditions (with this fraction captured by the profitability ratios included in the regressions). The amortization coefficient (d) has already been considered in direct proportional multiples where, as we will see below, its explanatory power is quite limited, as proved by the fact that EV/EBITDA performs significantly better than EV/EBIT.

In sum, EV/EBIT and EV/EBITDA are calculated in three ways (arithmetic mean, median, and harmonic mean), while EV/S and EV/IC are calculated in five ways, the three just mentioned plus two regressions.

The use of this kind of linear regression assumes as negligible the differences in terms of cost of capital and growth prospects not already captured in the slope and the intercept.

Accuracy is measured using median absolute percentage error (MAPE), the absolute value of the difference between estimated price and actual price, scaled by actual price, one of the various measures of error that can be found in the literature. We motivate our choice, aware that definition of pricing error is relevant for accuracy valuation (Dittman and Maug, 2008), with the fact that absolute error captures both over- and undervaluation, while the median allow us to avoid the effect of outliers (cases of very high over or undervaluation). ${ }^{18}$

\section{Results}

We show results of our analysis under two different perspectives. First, in table 4, we report the average values of MAPE for all cyclical companies over the entire decade. These data allow us to compare the accuracy of different multiples and the way in which multiples are calculated, making reference to all considered cyclical firms over a long period. Second, in table 5 and 6, we analyze the accuracy of the four considered multiples in each of the 10 years, thus giving an idea of stability of estimations over time.

\subsection{Whole Sample, All Years}

Table 4 reports MAPE for tested multiples; in each year, we calculate current multiples and, for EV/EBIT, EV/EBITDA, and EV/S, historical multiples, averaging the denominator of multiples based on income statement drivers over two, three, and four years. For this reason, we have, for these multiples, four values of MAPE. In the case of EV/IC we have, in contrast, only the current multiple for each year. For EV/S and EV/IC we also have, for each year, two additional values each, coming out of the regressions operated; as a consequence, these two multiples are calculated in five ways instead of three. Values of MAPE reported in Table 4 are the 10-year averages of median errors obtained in each one of the 10 years.

a) Accuracy of proportional multiples.

Multiples comparison. Comparing multiples calculated according to the direct proportionality criterion, EV/EBITDA emerges by far as the most accurate in estimation, with an error of $31.0 \%$ (median of current multiple), followed by EV/EBIT (35.7\%, harmonic mean, two-year average of EBIT), EV/IC (40.2\%, harmonic mean) and EV/S (51.8\%, median of current multiple), which provide significantly worse estimations compared to the other three.

Multiples calculation. Considering the way in which multiples are calculated, we find that best estimates are provided by the median and the harmonic mean, while arithmetic mean produces in all cases the worst estimates. In the case of EV/EBIDA, the estimation obtained through the arithmetic mean is worse compared to median and harmonic mean but is better than the best estimations obtained with the other three multiples. This suggests that EV/EBITDA dominates the other three multiples in terms of accuracy.

Historical vs current multiples. Interestingly, EV/EBITDA and EV/S provide the best estimations considering current multiples, and the accuracy of estimation worsens when the averages of drivers are considered instead of current ones. To the contrary, the best estimation accuracy of EV/EBIT is found by making the average two-year EBIT the denominator of the multiple.

b) Results obtained through regression analysis.19 For the reasons outlined in paragraph 3.2.3, we have

\footnotetext{
${ }^{17}$ This hypothesis holds true, for European companies, at least until the second half of 2011.

${ }^{18}$ According to Alford (1992), this measure of error gives equal importance to positive and negative errors; as the distribution of this error measure is right skewed, accuracy may be estimated using the median of error.

${ }^{19}$ In table 8 , we present the results about the average accuracy (mean squared R) of the regression performed.
} 
calculated EV/S and EV/IC through single-factor regression analysis, using as independent variables EBIT/S and EBITDA/S in the first case and EBIT/IC and EBITDA/IC in the second case. Estimation accuracy of the two multiples improves dramatically in both cases, but, in the case of EV/S, which provided the worst estimates using proportional multiples, estimation error is still greater than the one obtained through (proportional) EV/EBITDA. EV/IC is the best estimator of our sample, with a MAPE around 29\% in both cases. In other words, the way in which multiples are calculated seems to make the difference in terms of quality of estimations.

\subsection{Analysis of Estimation Accuracy over Time}

Table 5 reports MAPE for tested multiples for each year.

\section{a) EV/EBIT}

The accuracy of the current proportional multiples estimation remains substantially stable over time, with an error ranging between $30 \%$ and 34\%, except for the crisis years (2008/2009) and 2003, when estimation error is significantly greater, producing significant impact on the decade average. The best estimates are obtained in the pre-crisis period (2005-2006). The median and harmonic mean consistently produce better estimates compared to the arithmetic mean.

Putting in the denominator the average EBIT of two to four years significantly improves the estimation only for 2009, when the crisis weakens significantly the accuracy of current multiples. In other years, some improvements in terms of accuracy may be found by averaging EBIT, but the benefit is often limited. Overall, the current multiple provides the best estimate in two out of 10 years, while the two-year averaged EBIT gives the best result in six years, and the four-year average in two.

\section{b) EV/EBITDA}

Results provided by this multiple are clearly the best compared to other proportional multiples; in seven of the 10 years considered, MAPE ranges from $24.6 \%$ to $26.2 \%$, while the error increases significantly in 2008 (less in 2009) and 2003 but less than in the case of EV/EBIT. The best estimations are obtained in 2005-2006, just before the outbreak of the crisis. Even in the case of EV/EBITDA, the best results are obtained through the median (four times) and harmonic mean (six times) but, contrary to what we found for EV/EBIT, estimates obtained through the arithmetic mean are not so far from those obtained through the best estimators (median and harmonic mean). In the case of this multiple, the contribution given by putting in the denominator the average EBITDA is very limited; the best estimates are obtained five out of 10 times by using current multiples and, in the five other cases, by using an average calculated on two years. Calculating average of EBITDA over longer periods produces similar or worse results.

\section{c) $\mathrm{EV} / \mathrm{S}$}

Estimation error is significantly larger than in the cases of EV/EBIT and EV/EBITDA, with the best estimates implying a mispricing of more than $40 \%$. (43.2\% is the best result, obtained for 2006, while in 2005 error is $45.7 \%$.) In 2008, the results worsen significantly, as in the case of other two multiples. Averaging sales over two to four years doesn't significantly contribute to estimation accuracy. In six out of 10 cases, the best estimations are provided by the current multiple; in one case, by the two-year sales average; and in three, by the three-year average. In four cases, the best estimation is provided by the harmonic mean; in five cases, by the median; and in one case, the two estimators provide the same result.

\section{d) $\mathrm{EV} / \mathrm{IC}$}

Estimation error obtained with this multiple is larger than the one provided by EV/EBIT and EV/EBITDA and smaller than that found through EV/S. The best estimation is obtained in 2005 (38.2\%, median of MAPE). The harmonic mean (seven times) and median (three times) provide much better estimates compared to arithmetic mean: the results are more stable in the course of years, and even in periods, like the financial crisis and 2003, in which accuracy of other multiples decreases significantly.

e) Results obtained through regression analysis (table 6)

In table 6, we report results obtained in the course of the 10 years through regression analysis, calculating EV/S as a function of EBIT and EBITDA margin and EV/IC as a function of EBIT/IC and EBITDA/IC. Results are quite interesting as the accuracy of the two multiples increases dramatically compared to the case in which they have been calculated according to direct proportionality.

The independent variables used in regressions can always explain a large portion of the multiple cross section variability. 
As far as EV/S is concerned, we find the best results using EBITDA margin as independent variable in the regression six times out of the 10 years considered and three times using EBIT margin. Once we find the same results using the two margin ratios. In five cases, the best estimation is provided by current margin, in three, by the two-year average, and in two cases, the current and two-year average provide the same results. Using averages referring to a longer period worsens accuracy. This way of calculating the multiple gives to EV/S a level of accuracy that is not far from that of proportional EV/EBITDA.

Coming to $\mathrm{EV} / \mathrm{IC}$, it is possible to see how its calculation through a single-factor regression where the independent variable is the profitability ratio of invested capital provides very good level of estimation accuracy. Nine out of ten times the best results are obtained using EBIT/IC as independent variable and only once using EBITDA/IC. The results obtained through regression analysis beat those obtained through proportional EV/EBITDA in eight out of 10 cases. In the other two, the difference is so small to be considered immaterial $(0.2 \%$ and $0.3 \%$ respectively). In seven out of 10 years, both results obtained through regressions are better than those obtained through proportional EV/EBITDA.

The results obtained may be considered quite good even in absolute terms: apart from 2003, 2008, and 2009, MAPE is lower than 30\% - in some years (2005 and 2006), significantly lower. Even in the three years in which estimation accuracy is generally weaker, MAPE increases but less than for other multiples.

\subsection{Robustness Check: Sector Analysis}

The results obtained may depend on the definition of the sample and the definition of cyclical firm. It should be recalled that the literature has not identified a unique way to identify a firm as cyclical: the definition of cyclical company refers to a sector, without providing a clear distinction between cyclical and non-cyclical sectors. In order to verify the robustness of the results obtained, we have carried out our anal ysis even at the sector level.

In table 7 , we analyze the accuracy of estimation within each of the eight sectors composing our sample, to verify whether accuracy is stable among them.

Repeating the analysis for each one of the eight sectors considered in our sample, we obtained results reported in table 7, which can be summarized as follows.

a) MAPE, for each sector/all years, ranges from a minimum of $25.8 \%$ (basic materials) to a maximum of $31.4 \%$ (cyclical goods). In seven out of eight cases, MAPE is lower than $30 \%$ and, in four cases, lower or equal to $28 \%$.

b) EV/IC calculated through regression analysis produces the best estimate in seven out of the eight cases. In the eighth case (Retail sector), the most accurate estimate is provided by EV/EBITDA (two-year average). In the calculation of EV/IC, EBIT margin is the best-performing independent variable in five cases, while EBITDA margin produces better estimates in the other three cases (but in one of these three, both multiples are beaten by EV/EBITDA, two-years average).

c) Among the four proportional multiples, EV/EBITDA ranks always first, and EV/S always fourth; EV/EBIT is six times second and two times third; and EV/IC is two times second and six times third. Differences in accuracy between the best-performing multiple (EV/EBITDA) and the second is quite significant $(4.7 \%$ on average, with a minimum of $3 \%$ and a maximum of $7.4 \%$ ), while the difference between the first and the third in rank is much bigger (9.9\% on average with a minimum of $4.5 \%$ and a maximum of $15.3 \%$ ). The performance of $\mathrm{EV} / \mathrm{S}$ is so poor, compared to EV/EBITDA, that results seem to recommend against using this multiple in the proportional version.

d) Accuracy of EV/S increases dramatically within all sectors when the multiple is calculated through regression analysis. MAPE is significantly reduced in this case and approximates EV/EBITDA, being larger, on average, by $1.9 \%$. These results suggest the use of EV/S only when this multiple is calculated through regression analysis, using EBITDA margin as independent variable (providing better estimates in seven out of eight cases).

e) Considering the four proportional multiples, we can measure the impact of the way in which they are calculated (arithmetic mean, median or harmonic mean). Sectors analysis confirms the results already shown in table 4 (all sectors/all years): considering each of the eight sectors, the 10-year average MAPE of the four multiples ( 32 observations), we find that the harmonic mean provides the best estimate in 18 cases, and the median in 12 . In one case, the two estimators provide the same result and in one case only the arithmetic mean provides the best estimate.

f) Finally, comparing current and historical multiples, we find mixed results. The best-performing proportional multiple, EV/EBITDA, provides the best estimates using current EBITDA in four out of eight cases. In three cases, accuracy increases using the two-year average, and in one case, using the four-year average. In 
the case of EV/EBIT, averaging seems to help in terms of accuracy as only in two cases are the best results obtained using current EBIT. In the other six, averaging (three times two years, two times four years and once three years) provides better performance. Even evidence about EV/S is quite mixed: proportional EV/S yields best results three times using current sales, twice using the four-year average, and once using the two-year average. In two cases the best results are provided by two multiples simultaneously (current and two-year average; two- and four-year averages). Calculating EV/S through regressions, the best estimates are obtained five times using current margin, once using the four-year average, once using the two-year average, and once by both current and two-year margin

\subsection{Comparison with Results Obtained by Authors Using the Same Definition of Error}

Alford (1992), analyzing estimation accuracy of PE on the basis of different criteria for comparables selection, finds a level of estimation error of $23.9 \%$ for the best-performing selection criterion (industry and ROE). This result is obtained averaging median absolute percentage error for the three years considered in his analysis. Cheng and McNamara (2000), conducting an analysis similar to that of Alford but on a longer period, find that estimations through PE yield an error of $26.4 \%$ when comparables are selected on the basis of both industry and ROE criteria.

Another comparison is the work of Deng, Easton \& Yeo (2010), who do an extensive analysis over 25 years considering current data only and including firms with negative fundamentals. When calculating multiples according to the direct proportionality criterion, using the median and harmonic mean, they find a level of accuracy which is lower than ours. 1) Using the harmonic mean to calculate multiples, they obtain a mean (median) absolute valuation error of $51 \%(47 \%)$ for the best-performing asset-side multiple $\left(\mathrm{EV} / \mathrm{NOA}^{20}\right)$, while the best-performing equity-side multiple (P/BV) yields a mean (median) error of $51 \%(48 \%)$. 2) Calculating multiples through median, the maximum level of accuracy is obtained through the same two multiples with a mean (median), with errors of $50 \%(45 \%)$ and $48 \%$ (43\%). When they use regression analysis, the results improve significantly: mean (median) absolute valuation error value for the best-performing asset-side multiple (EV/NOA) is $41 \%(34 \%)$, while the best-performing equity-side multiple (PB) yields a mean (median) error of $41 \%(34 \%)$. Valuation error found by these authors is further reduced when the valuation is conducted by combining multiples. Using jointly EV/NOA and EV/EBITDA leads to a mean (median) error of 35\% (29\%), and $34 \%(27 \%)$ is reached when the restriction of a non-negative EBITDA is imposed. Similar results are obtained combining, under an equity-side perspective, P/BV and P/EBITDA (34\% the mean error and $27 \%$ the median error), this time imposing the restriction of a negative EBITDA.

In their analysis of multiples' accuracy in European equity markets, Schreiner and Spremann (2008) consider a list of 27 equity multiples, 10 of which are forward looking. Among the 17 current multiples considered, the best-performing one, a knowledge-related multiple, ${ }^{21}$ has a mean (median) error of $44.45 \%(25.37 \%)$. Results improve considering forward-looking multiples, with a minimum mean and median error of $31.68 \%(\mathrm{P} /$ two years earnings) and $21.51 \%$, respectively (P/ two-year earnings before taxes). Repeating the analysis on the U.S. market, the accuracy of estimation improves, with a median error $2.3 \%$ smaller, on average, compared to results obtained in European markets. The best-performing multiple, price scaled by earnings plus amortization of intangible assets, provides an error smaller by $1.62 \%$.

\section{Conclusion}

Valuation through market multiples is an everyday practice in financial markets, but fewer studies on this subject have been published than one would expect. More than this, the issue of the valuation of cyclical companies, a relevant practical problem given the large number of cyclical firms, has received almost no attention in the literature. Authors who deal with this subject, mainly in textbooks, point out two main issues. The first is that the valuation of these companies is more complex than that of noncyclical firms, and the second is that their valuation should be approached considering average firm performance over an entire cycle to account for the variability of performance over time. For this reason, they average firms' results, mainly profitability or cash flows indicators, and use them to support fundamental methodologies.

Given this evidence, we have tried to answer to three correlated research questions. First, we wanted to verify whether the methodology of multiples can be effectively used in estimating the value of cyclical companies.

\footnotetext{
${ }^{20}$ Net Operating Assets.

${ }^{21}$ Price scaled by earnings plus amortization of intangible assets, one of the six knowledge-related multiples used by authors in their accuracy analysis.
} 
second, we wanted to see whether and how the way in which multiples are calculated, one of the basic pillars of the methodology, has a significant impact on the accuracy of estimations. Third, we empirically tested the idea that in the valuation of cyclical companies the basis of the multiple should be determined taking into account the average (over the cycle) economic or financial performance of the company.

Using a sample of listed European cyclical companies over the decade of 2003 - 2012, we find interesting results. First, the overall level of accuracy of our estimations is quite similar to that found by authors who have analyzed the estimation performance of multiples using samples including both cyclical and noncyclical companies. This result is especially interesting since the period over which we carried out our analysis includes the crisis years, when the market turbulence exasperated market volatility, with obvious consequences on the performance of a market-based methodology. Secondly, our results suggest that EV/EBITDA is by far the most accurate estimator among proportional multiples; the median and the harmonic mean appear to be the best ways in which this multiple should be calculated, and current EBITDA is, in almost all cases, the economic driver providing best estimates. Third, the idea of averaging results over longer periods to account for specific features of cyclical companies does not seem to generate superior estimations through the multiples methodology, at least for the best proportional multiple (EV/EBITDA). Averaging produces some improvements in valuation performance only for multiples yielding poorer results. Fourth, results obtained through regression analysis indicate that the way in which multiples are calculated really matters. Our findings suggest that combining, through regression analysis, a balance sheet-based multiple (EV/IC) and a profitability driver (EBIT/IC or EBITDA/IC) is an effective way to reach a good level of accuracy in estimation.

Table 1. Literature review

\begin{tabular}{|c|c|c|}
\hline Alford (1992) & Kaplan and Ruback $(1995,1996)$ & Cheng and McNamara (2000) \\
\hline $\begin{array}{l}\text { OBJECTIVE: test PE accuracy sensitivity } \\
\text { to comparables' choice }\end{array}$ & $\begin{array}{l}\text { OBJECTIVE: co mparing re lative accuracy } \\
\text { of DCF and market multiples }\end{array}$ & $\begin{array}{l}\text { OBJECTIVE: test the valuation accuracy } \\
\text { of the PE, the PB and a combination of } \mathrm{PE} \\
\text { and } \mathrm{PB} \text { (equally weighted) }\end{array}$ \\
\hline $\begin{array}{l}\text { ERROR DEFINITION: Absolute \% error: } \\
\text { (Predicted price -Actual price) / Actual price }\end{array}$ & $\begin{array}{l}\text { ERROR DEFINITION: natural log of } \\
\text { estimated value to transaction value }\end{array}$ & $\begin{array}{l}\text { ERROR DEFINITION: percentage } \\
\text { absolute error scaled by actual price } \\
\text { (PAE/A); percentage absolute error scaled } \\
\text { by predicted price (PAE/P); adjusted } \\
\text { percentage absolute error (APAE), adding at } \\
\underline{\text { the absolute error at the denominator of }} \\
\text { PAE/P; the square root of APAE }\end{array}$ \\
\hline $\begin{array}{l}\text { SAMPLE: NYSE, ASE and OTC firms for } \\
\text { the years 1978, } 1982 \text { and 1986. Ebit and } \\
\text { Earnings both positive. }\end{array}$ & $\begin{array}{l}\text { SAMPLE: } \\
\text { transactions }\end{array} 51$ Highly $\quad$ Leveraged & $\begin{array}{l}\text { SAMPLE: All firms from the } 1992 \\
\text { Compustat }(1973-1992, \text { only positive } \\
\text { earnings and book value) }\end{array}$ \\
\hline COMPARABLES, & COMPARABLES, & COMPARABLES, \\
\hline CRITERIA: & CRITERIA: & CRITERIA: \\
\hline Market & i) firms in the same industry; ii) firms & Market \\
\hline Industry (3 SIC ) & involved in similar transactions; iii) firms & Industry (4 SIC ) \\
\hline & both in the same industry and involved in & TA \\
\hline Roe & similar transactions & Roe \\
\hline Industry $+\mathrm{TA}$ & & Industry + TA \\
\hline Industry + Roe & & Industry + Roe \\
\hline $\mathrm{TA}+\mathrm{ROE}$ & & \\
\hline MTP CALCULATION: Median mtp & MTP CALCULATION: Median mtp & MTP CALCULATION: Median mtp \\
\hline $\begin{array}{l}\text { MAIN RESULTS: Greater PE accuracy } \\
\text { when comparables are selected on the basis } \\
\text { of: industry or pairs of Industry, TA and } \\
\text { ROE. }\end{array}$ & $\begin{array}{l}\text { MAIN RESULTS: The method of multiples } \\
\text { performs almost as well as the DCF and the } \\
\text { use of both is recommended }\end{array}$ & $\begin{array}{l}\text { MAIN RES ULTS: The main difference } \\
\text { with Alford's findings is that combining } \\
\text { industry and ROE as selection criteria for } \\
\text { comparable firms provide significant better } \\
\text { estimations than considering only industry. } \\
\text { PE performs better than the PB and the } \\
\text { combined PE-PB method performs better } \\
\text { than the PE alone. }\end{array}$ \\
\hline
\end{tabular}


$\frac{\underline{\text { Kim and Ritter (1999) }}}{\text { OBJECTIVE: }}$

SAMPLE: 190 domestic operating company IPOs

\section{COMPARABLES SELECTION CRITERIA:}

a) recent IPOs in the same industry (four-digit SIC code);

b) comparables identified by a research boutique specializing in the valuation of IPOs

MTP CALCULATION: a) regression approach (the dependent variable being the multiple for the valuation of the IPO and the independent variable being the median multiple of comparables)

b) simple approach, using the mean or median multiple of comparables

ERROR DEFINITION: natural log of the ratio of the predicted multiple to actual multiple

MAIN RESULTS: a) PE, PB, PS:

i) using regression, recent IPOs from the same industry as comparables, and historical numbers, gives very poor results in terms of estimation accuracy

ii) using comparables provided by the financial boutique and moving from historical to forecasted earnings improves substantially estimation accuracy (forecasted earnings are more important than more accurate comparables selection);

iii) including growth does not increase accuracy when next-year forecasts are considered;

iv) accuracy is greater for old firms than for young ones;

v) different calculation of multip les - regression approach versus simple calculation

- has mixed effect on estimation accuracy.

b) EV multiples (EV/S and EV/EBITDA)

i) EV/S performs much better than $\mathrm{P} / \mathrm{S}$ (which performs as bad as historical earnings in the PE estimation);

ii) EV/EBITDA performs better (as well as PE estimation when current year forecasts are considered) than EV/S, especially for old firms;

iii) finally, when using the EV/Sales multiple as valuation benchmark, the authors find that profitability and growth have a positive impact on the level of multiple (about 20\% premium). Accuracy is greater for old firms (for which profitability matters much more than growth) than for new ones; results obtained using EV/S are less accurate than those obtained using forecasted earnings when the PE is assumed as valuation benchmark.

Liu, Nissim, and Thomas (2002)
OBJECTIVE: comparing the valuation

performance of a long and comprehensive list of multip les (17), based on different value drivers, with the purpose of identifying the best-performing ones.

SAMPLE: firms representing between 11 and $18 \%$ of NYSE + AMEX + NASDA Q companies, (1982 and 1999); only firms showing positive multip les are considered.

\section{COMPARABLES SELECTION CRITERIA:}

a) entire cross section of firms

b) comparables from the same industry

\section{MTP CALCULATION:}

a) harmonic mean, b) median, and c) regression analys is

ERROR DEFINITION: (Predicted price -Actual price) / Actual price

MAIN RES ULTS: a) forward earnings are the most relevant value driver and (valuation performance increases for longer time horizons), while multiples based on measures of intrinsic value perform significantly worse than forward earnings

b) considering historical data, the dispersion of pricing errors increases substantially (sales perform the worst, while earnings perform better than book value)

c) multiples based on cash flow measures perform generally bad

d) when sales and EBITDA are used as value drivers, EV multiples perform worse than equity multiples

e) harmonic mean performs better than median, and the regression approach increases the valuation performance of poorly performing multiples; no significant improvements are found for the most performing ones

f) the common practice of selecting firms from the same industry gives better results than considering as comparables all the firms included in the cross section

g) relative performance of multiples is relatively stable over time and across industries

Beatty, Riffle, and Thompson (1999)
OBJECTIVE: investigate the effect of how multiples are
calculated on their respective accuracy
SAMPLE: All Compustat firms from 1980 to 1992 meeting some
conditions
COMPARABLES SELECTION CRITERIA:
three-digit SIC Code

\section{MTP CALCULATION:}

eight methodologies, six of which include only earnings and book value, the seventh adds dividends and the eighth total assets. The first five models are proportional, as they do not contain an intercept. Four out of these five models equally weight PE and PB; the difference between one methodology and the others is the way in which multiples are calculated, while in the fifth model, weights are empirically derived.

The other three models are linear regressions containing an intercept. In the first of these three, the regression includes only earnings and book value (as in the first five models), while the second includes dividends, and the last dividends and total assets.

ERROR DEFINITION: (actual price - predicted price)/actual price (mean value is considered)

\section{Lie and Lie (2002 \\ OBJECTIVE: investigate valuation performance of different multiples (10) \\ SAMPLE: all Compustat active firms, data for fiscal year 1998 (forecast refer to 1999) \\ COMPARABLES SELECTION CRITERIA: \\ industry criterion (three-d igit SIC code, when at least five comparable were available, if not, two-digit SIC code) \\ MTP CALCULATION: median value of comparable firms}

ERROR DEFINITION: natural logarithm of the ratio between estimated value and market value 
MAIN RES ULTS: a) equally weighting average PE an PB leads to the worst results

b) the model based on inverse average (e/P and b/P) performs much better

c) the deflated regression weights model (where the weights are not defined ex ante- as in the first four models - but are derived empirically from market analysis) is the best-performing among proportional models

d) among the three linear models, the best estimates are provided by the first one, which includes, as independent variables, only earnings and book value of equity. Including in the regression even dividends and size (total assets) leads to an increase in pricing error

\section{MAIN RESULTS:}

I) a) between the two earnings based multiples, the forecasted PE clearly outperforms the other, based on historical earnings;

b) adjusting EV and book value of assets for cash levels does not produce any material effect on results

c) among EV multiples, book value (EV/book value of assets) provides the best estimates, while EV/Sales perform the worst. The other two multiples, EV/EBITDA and EV/EBIT, lie in between, with the former performing better than the latter

II) separating financial from nonfinancial and grouping on the basis of size and profitability: i) valuation tends to be more accurate for larger than smaller companies (undervaluing the former and overvaluing the latter; ii) independently from company size, asset multiples outperform equity multiples, with the EV/Book Value of Assets performing the best and the EV/Sales performing the worst; iii) companies with low / medium profitability levels are better estimated through the asset multiples (although positively biased), while multiples based on earnings provide, as expected, poor estimation for low earnings companies. (In this case, in an equity-side approach, forecasted earnings perform better than current earnings). Earnings multiples (EV/EBITDA and EV/EBIT) perform as well as the asset multiple (EV/Book Value of Assets) for companies with high earnings; iv) considering that earnings multiples are positively biased while asset and sales multiples are negatively biased, the authors decide to consider both, checking the valuation performance of a hybrid measure made of both the asset and the EBITDA multiples (equally weighted): this hybrid measure performed better than individual multiples; v) quite surprisingly, the authors find that the valuation accuracy of multiples is greater in the case of financial companies, where results show higher performance for EV multiples even if, we observe, these companies are rarely estimated under an asset-side approach; vi) multiples generate poor valuation performances in the case of companies with high levels of intangibles

\begin{tabular}{l} 
Schreiner and Spremann (2007) \\
\hline OBJECTIVE: investigate the estimation accuracy of market \\
multiples: i) equity side vs assert side multiples; ii) 'knowledge based' \\
multiples vs traditional multiples in science based industries; iii) \\
forward looking multiples vs trailing multiples \\
$\frac{\text { SAMPLE: }}{1996-2005}$
\end{tabular}

COMPARABLES' SELECTION CRITERIA: industries and subindustries according to the ICB classification system, provided by DJ and FTSE

MTP CALCULATION: median multiple

ERROR DEFINITION: scaled absolute valuation errors, defined as the absolute difference between predicted and actual price, scaled by actual price

MAIN RESULTS: i) equity side mu ltiples perform better than asset side multiples; authors hold that the reason is to be found in the uncertainty in the estimation of market value of debt (and EV (as a consequence, iln the following part of the analysis only equity side multiples are considered); ii) 'knowledge related' multiples (considering R\&D expenditures and amortization of intangibles) perform better than traditional ones in the case of science based industries; iv) forward multiples are more accurate than trailing ones

Bhojraj and Lee (2002)

OBJECTIVE: developing a more systematic technique for selecting comparable firms and finding out the comparables which allow the best estimation of the target firm's future multiples (one, two and three years ahead EV/Sales an PB, in the specific case)

SAMPLE: all firms in the intersection of (a) the merged COMPUSTAT industrial and research files, and (b) the I/B/E/S historical database of analyst earnings forecasts, excluding ADRs and REITs, for the period 1982-1998.

COMPARABLES' SELECTION CRITERIA: firms which have 'warranted multip les' (calculated on the basis of fundamental drivers) closest to the one of the target firm

MTP CALCULATION: multiple regression model ERROR DEFINITION: _Absolute Error, defined as the absolute difference between actual and implied price, scaled by the actual price

MAIN RESULTS: identifying comparables on the basis of 'warranted multiples' significantly increases the accuracy of estimation of future multiples compared to the case in which comparables are selected solely on an industry/size basis

\begin{tabular}{|c|c|}
\hline Deng, Easton, and Yeo (2010) & Harbula (2009) \\
\hline $\begin{array}{l}\text { OBJECTIVE: analyze multiples accuracy, comparing asset-side and } \\
\text { equity-side multiples }\end{array}$ & OBJECTIVE: \\
\hline $\begin{array}{l}\text { SAMPLE: all companies listed on NYSE, AMEX, and NASDAQ } \\
\text { with firm/year observations for the period of } 1963-2008\end{array}$ & $\frac{\text { SAMPLE: }}{(1986-2009)} 400$ companies selected from the DJ STOXX 600 \\
\hline
\end{tabular}




COMPARABLES' SELECTION CRITERIA: four-digit SIC code

\section{MTP CALCULATION:}

a) harmonic mean and median; b) regression analysis;

c) combination of multiples

ERROR DEFINITION: absolute valuation error, defined as the absolute difference between predicted and actual price, scaled by actual price

\section{MAIN RESULTS:}

a) harmonic mean and median: among EV multiples, NOA is the driver that provides the lowest mean valuation error, closely followed by sales; EBITDA ranks third and free cash flow performs the worst; among equity multiples, the best performance is provided by $\mathrm{BV}$, while sales provides higher errors, and errors are much higher in the case EBITDA and net income are considered as value drivers

b) regression analysis: improvement in the valuation performance of all multiples, especially for those performing worse in the first stage of the analysis and a partial change in the ranking of multiples

c) combination of multiples: combining two multiples may increase significantly valuation performance. The best estimations are those obtained combining NOA and EBITDA for enterprise valuation and $\mathrm{BV}$ and EBITDA for equity-side valuation. Combining sales - a usefu value driver that can be easily used when others are negative - with an income measure, produces an improvement in valuation performance. Differences in valuation accuracy are not relevant between firm with positive and negative income fundamentals, and in some cases results show that pricing errors based on sales are smaller for firms with negative fundamentals, compared to firms with positive ones

\section{COMPARABLES' SELECTION CRITERIA:}

a) industry criterion

MTP CALCULATION: both direct proportionality and

regression analys is

ERROR DEFINITION: absolute mean and median error margin versus actualprice

\section{MAIN RESULTS:}

a) comparables from the same industry: i) prospective multiples perform better than current or historical (especially earnings driven multiples); ii) profitability-based multiples prove to be the more accurate, especially when based on current and forward figures (vs. historical); iii) as set-side multiples perform better than equity-side ones; iv) combining multiples increases the accuracy (current and forwardand/or different multiples); v) there is not a multiple fitting all industries

b) regression analysis: a list of potential drivers are tested in a single-factor regression analysis to identify those that better explain the difference between the multiples of a given firm and the industry/sample median. Most relevant drivers are selected for a multifactor regression analysis carried out to verify the importance of different drivers in explaining the level and evolution of valuation multiples for every firm. The main findings are the following: i) growth has a strong impact on all the considered multiples; ii) profitability has a positive impact on all multiples not including a direct measure of profit (EV/Sales, EV/Invested Capital), while its effect is more ambiguous for multiples based on direct profit measure; iii) stability of profitability and growth appear to be important drivers of market multiples; iv) EV multiples have a mildly positive correlation with financial leverage up to a certain level and then the relationship turns negative; equity multiples have a negative correlation with financial leverage as long as it remains with in reasonable level and then in turns strongly positive; v) size and liquidity profile are almost immaterial; vi) in many cases the relationship between multiples and financial drivers is not linear, highlighting the need for additional analysis

\section{Hermann and Richter (2003)}

OBJECTIVE: investigate all relevant issues of the methodology: comparables' selection, drivers of the multiples and calculation (with specific focus on the first aspect)

SAMPLE: 524 largest (in terms of market cap) US firms and 830 large European firms

COMPARABLES' SELECTION CRITERIA: a) all sample firms; b) SIC codes (starting with four-digit and reducing the number until four firms are identified; c) fundamental factors; d) like c) plus long-term growth rates from IBES; e) combination of b) and d)

MTP CALCULATION: arithmetic mean, median, harmonic mean, regression analysis

ERROR DEFINITION: absolute value of the difference between the natural log of predicted price and the natural log of actual price

MAIN RESULTS: a) multiples based on earnings lead to best estimates and sales-based multiples to the worst. PB produces much better estimates (compared to EBIDAAT and EBIAT) when companies are selected on the basis of ROE and earnings growth instead of industry criterion; b) selecting comparables on the basis of fundamental drivers (namely, earnings growth and ROE) leads to better results. Selecting firms on the basis of both fundamentals and industry me mbership does not imp rove accuracy; c) median appears as the best estimator, followed by the mean, while arithmetic mean and harmonic mean provide less accurate estimations. Using regression analysis for controlling for fundamental factors gives worse results than using the median of comparable firms selected on the basis of similar fundamental factors.

\section{Tremolizzo (2009)}

OBJECTIVE: compare the accuracy of multiple in estimating cyclical and noncyclical companies

SAMPLE: 174 companies listed on the London Stock Exchange from 1995 to 2007, 101 from cyclical industries and 73 from noncyclical ones

COMPARABLES' SELECTION CRITERIA: two-digit SIC Code (28, 36, 33 and 37 for cyclical companies; 20, 24, 21, 49 for noncyclical)

\section{MTP CALCULATION: average and median multiples}

ERROR DEFINITION: absolute value of the difference between the natural log of predicted price and the natural log of actual price MAIN RESULTS: a) using PE, forward PE, EV/EBIT and EV/EBITDA, estimates of cyclical companies are less accurate than estimates of noncyclicals. Difference in accuracy increases adjusting EV multiples for cash and cash equivalents; b) using regression analysis, valuation error is found to be positively correlated with cyclicality and EBIT volatility and negatively correlated with size; c) logit analysis confirms that cyclicality and EBIT volatility are associated with larger valuation error, while size has the opposite effect 
Table 2. Sample structure

\begin{tabular}{llc}
\hline Industry & Sector & Number of Observations \\
\hline \multirow{2}{*}{ Basic Materials } & [1] Basic Resources & 150 \\
& [2] Chemicals & 97 \\
\multirow{4}{*}{ Consumer Cyclical } & [3] Automobiles & 70 \\
& [4] Cyclical Goods and Services & 381 \\
& [5] Media & 209 \\
\multirow{4}{*}{ Industrial } & [6] Retail & 111 \\
& [14] Construction & 217 \\
Sum & [15] Industrial Goods and Services & 698 \\
\hline
\end{tabular}

Table 3. Mean Coefficient of Variation of Different Multiples (2003-2012)

\begin{tabular}{lcc}
\hline Multiple & Coefficient of Variation & $\begin{array}{c}\text { average number of } \\
\text { observations }\end{array}$ \\
\hline EV / Sales & 0,33 & 865 \\
EV / EBITDA & 0,33 & 819 \\
EV / EBIT & 0,36 & 776 \\
EV / Invested Capital & 0,39 & 682 \\
Price / Earnings & 0,51 & 890 \\
Price / Cash Flows & 0,45 & 734 \\
Price / Book Value & 0,44 & 846 \\
\hline
\end{tabular}

Table 4. Median Absolute percentage error; 2003 - 2012

\begin{tabular}{|c|c|c|c|c|}
\hline & \multicolumn{4}{|c|}{ Core Enterprise Value / EBIT } \\
\hline & $\begin{array}{ll}\text { four } & \mathbf{t} \\
\text { years } & \mathbf{y} \\
\text { Ebit } & \mathrm{E} \\
\text { average } & \text { a }\end{array}$ & $\begin{array}{l}\text { three } \\
\text { years } \\
\text { Ebit } \\
\text { average }\end{array}$ & $\begin{array}{l}\text { two } \\
\text { years } \\
\text { Ebit } \\
\text { average }\end{array}$ & Current \\
\hline Arithmetic mean & $43,30 \%$ & $43,40 \%$ & $43,60 \%$ & $48,90 \%$ \\
\hline Median & $37,40 \%$ & $36,80 \%$ & $36,20 \%$ & $37,60 \%$ \\
\hline \multirow[t]{3}{*}{ Harmonic mean } & $36,70 \%$ & $36,20 \%$ & $35,70 \%$ & $36,80 \%$ \\
\hline & \multicolumn{4}{|c|}{ Core Enterprise Value / EBITDA } \\
\hline & $\begin{array}{c}\text { four } \\
\text { years } \\
\text { Ebitda } \\
\text { average }\end{array}$ & $\begin{array}{c}\text { three } \\
\text { years } \\
\text { Ebitda } \\
\text { average }\end{array}$ & $\begin{array}{c}\text { two } \\
\text { years } \\
\text { Ebitda } \\
\text { average }\end{array}$ & Current \\
\hline Arithmetic mean & $35,10 \%$ & $33,70 \%$ & $32,80 \%$ & $32,50 \%$ \\
\hline Median & $33,00 \%$ & $32,30 \%$ & $31,30 \%$ & $31,00 \%$ \\
\hline \multirow[t]{3}{*}{ Harmonic mean } & $33,10 \%$ & $32,30 \%$ & $31,50 \%$ & $31,10 \%$ \\
\hline & \multicolumn{4}{|c|}{ Core Enterprise Value / Sales } \\
\hline & $\begin{array}{c}\text { four } \\
\text { years } \\
\text { Sales } \\
\text { average }\end{array}$ & $\begin{array}{r}\text { three } \\
\text { years } \\
\text { Sales } \\
\text { e averag } \\
\end{array}$ & 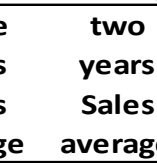 & Current \\
\hline Arithmetic mean & $58,40 \%$ & $57,40 \%$ & $57,00 \%$ & $56,40 \%$ \\
\hline Median & $53,00 \%$ & $52,30 \%$ & $52,00 \%$ & $51,80 \%$ \\
\hline Harmonic mean & $53,20 \%$ & $52,70 \%$ & $52,60 \%$ & $52,30 \%$ \\
\hline $\mathrm{EV} / \mathrm{S}=\alpha+\beta \times$ Ebit $/$ Sales & $38,10 \%$ & $37,50 \%$ & $36,40 \%$ & $36,80 \%$ \\
\hline $\mathrm{EV} / \mathrm{S}=\alpha+\beta \times$ Ebitda/Sales & $35,60 \%$ & $34,30 \%$ & $33,20 \%$ & $32,30 \%$ \\
\hline
\end{tabular}




\begin{tabular}{lc}
\hline & $\begin{array}{c}\text { Core EV / } \\
\text { Invested } \\
\text { Capital } \\
\text { (current) }\end{array}$ \\
\hline Arithmetic mean & $48,50 \%$ \\
Median & $40,40 \%$ \\
Harmonic mean & $40,20 \%$ \\
EV/IC $=\alpha+\beta \times$ Ebit/IC & $28,20 \%$ \\
EV/IC $=\alpha+\beta \times$ Ebitda/IC & $29,30 \%$ \\
\hline
\end{tabular}

Table 5. Values of Median Average Percentage Error in each year for each multiple; 2003 - 2012

\begin{tabular}{|c|c|c|c|c|c|c|c|c|c|c|c|c|c|c|}
\hline & & \multicolumn{4}{|c|}{ Core Enterprise Value / EBIT } & \multicolumn{4}{|c|}{ Core Enterprise Value / EBITDA } & \multicolumn{4}{|c|}{ Core Enterprise Value / SALES } & \multirow{3}{*}{$\begin{array}{c}\text { Core EV } \\
\text { Invested } \\
\text { Capital }\end{array}$} \\
\hline & & four years & three years & two years & & four years & three years & two years & & four years & three years & two years & & \\
\hline \multirow[t]{2}{*}{ Year } & Estimator & $\begin{array}{l}\text { Ebit } \\
\text { average }\end{array}$ & $\begin{array}{l}\text { Ebit } \\
\text { average }\end{array}$ & $\begin{array}{l}\text { Ebit } \\
\text { average }\end{array}$ & current & $\begin{array}{r}\text { EBITDA } \\
\text { average }\end{array}$ & $\begin{array}{l}\text { EBITDA } \\
\text { average }\end{array}$ & $\begin{array}{l}\text { EBITDA } \\
\text { average }\end{array}$ & current & $\begin{array}{l}\text { SALES } \\
\text { average }\end{array}$ & $\begin{array}{l}\text { SALES } \\
\text { average }\end{array}$ & $\begin{array}{l}\text { SALES } \\
\text { average }\end{array}$ & current & \\
\hline & $\begin{array}{l}\text { arithmetic } \\
\text { mean }\end{array}$ & $41,70 \%$ & $37,10 \%$ & $35,80 \%$ & $43,30 \%$ & $33,10 \%$ & $31,90 \%$ & $30,30 \%$ & $31,00 \%$ & $58,60 \%$ & $57,80 \%$ & $57,00 \%$ & $56,10 \%$ & $45,10 \%$ \\
\hline \multirow[t]{3}{*}{2012} & median & $35,30 \%$ & $32,90 \%$ & $30,90 \%$ & $33,80 \%$ & $31,40 \%$ & $31,30 \%$ & $29,20 \%$ & $30,40 \%$ & $54,90 \%$ & $54,60 \%$ & $54,50 \%$ & $54,60 \%$ & $41,60 \%$ \\
\hline & $\begin{array}{l}\text { harmonic } \\
\text { mean }\end{array}$ & $35,00 \%$ & $32,60 \%$ & $31,20 \%$ & $33,10 \%$ & $32,60 \%$ & $30,80 \%$ & $29,90 \%$ & $30,40 \%$ & $53,70 \%$ & $53,40 \%$ & $53,50 \%$ & $53,80 \%$ & $41,30 \%$ \\
\hline & $\begin{array}{l}\text { arithmetic } \\
\text { mean }\end{array}$ & $41,90 \%$ & $47,10 \%$ & $43,60 \%$ & $47,80 \%$ & $34,10 \%$ & $34,30 \%$ & $32,90 \%$ & $32,50 \%$ & $64,40 \%$ & $63,10 \%$ & $62,40 \%$ & $61,70 \%$ & $48,90 \%$ \\
\hline \multirow[t]{3}{*}{2011} & median & $35,80 \%$ & $35,70 \%$ & $33,80 \%$ & $33,20 \%$ & $33,00 \%$ & $32,20 \%$ & $30,70 \%$ & $29,90 \%$ & $56,60 \%$ & $55,70 \%$ & $56,30 \%$ & $55,90 \%$ & $41,40 \%$ \\
\hline & $\begin{array}{l}\text { harmonic } \\
\text { mean }\end{array}$ & $35,30 \%$ & $36,10 \%$ & $32,90 \%$ & $32,40 \%$ & $32,40 \%$ & $32,60 \%$ & $31,20 \%$ & $29,00 \%$ & $54,10 \%$ & $53,30 \%$ & $54,00 \%$ & $54,20 \%$ & $40,40 \%$ \\
\hline & $\begin{array}{l}\text { arithmetic } \\
\text { mean }\end{array}$ & $35,40 \%$ & $40,90 \%$ & $47,60 \%$ & $41,40 \%$ & $31,90 \%$ & $31,60 \%$ & $31,90 \%$ & $30,70 \%$ & $58,60 \%$ & $58,30 \%$ & $57,60 \%$ & $56,10 \%$ & $50,50 \%$ \\
\hline \multirow[t]{3}{*}{2010} & median & $32,30 \%$ & $32,80 \%$ & $37,10 \%$ & $33,60 \%$ & $30,40 \%$ & $31,20 \%$ & $31,50 \%$ & $29,70 \%$ & $52,70 \%$ & $51,90 \%$ & $52,80 \%$ & $51,80 \%$ & $42,30 \%$ \\
\hline & $\begin{array}{l}\text { harmonic } \\
\text { mean }\end{array}$ & $31,90 \%$ & $31,80 \%$ & $36,20 \%$ & $32,10 \%$ & $30,20 \%$ & $30,60 \%$ & $32,20 \%$ & $30,80 \%$ & $53,60 \%$ & $52,50 \%$ & $52,80 \%$ & $52,50 \%$ & $41,80 \%$ \\
\hline & $\begin{array}{l}\text { arithmetic } \\
\text { mean }\end{array}$ & $42,30 \%$ & $40,50 \%$ & $44,30 \%$ & $63,00 \%$ & $33,70 \%$ & $32,00 \%$ & $32,80 \%$ & $33,20 \%$ & $59,60 \%$ & $58,00 \%$ & $58,70 \%$ & $58,80 \%$ & $49,90 \%$ \\
\hline \multirow[t]{3}{*}{2009} & median & $37,50 \%$ & $36,70 \%$ & $35,90 \%$ & $43,20 \%$ & $31,60 \%$ & $31,00 \%$ & $30,90 \%$ & $30,50 \%$ & $52,90 \%$ & $52,70 \%$ & $53,00 \%$ & $54,60 \%$ & $39,20 \%$ \\
\hline & $\begin{array}{l}\text { harmonic } \\
\text { mean }\end{array}$ & $34,70 \%$ & $34,80 \%$ & $35,10 \%$ & $42,40 \%$ & $31,70 \%$ & $32,20 \%$ & $29,90 \%$ & $32,70 \%$ & $53,10 \%$ & $53,70 \%$ & $53,60 \%$ & $52,20 \%$ & $39,40 \%$ \\
\hline & $\begin{array}{l}\text { arithmetic } \\
\text { mean }\end{array}$ & $59,90 \%$ & $60,50 \%$ & $60,90 \%$ & $71,60 \%$ & $48,30 \%$ & $47,90 \%$ & $48,80 \%$ & $45,90 \%$ & $63,70 \%$ & $63,40 \%$ & $64,40 \%$ & $65,00 \%$ & $50,20 \%$ \\
\hline \multirow[t]{3}{*}{2008} & median & $53,70 \%$ & $54,00 \%$ & $54,10 \%$ & $56,10 \%$ & $46,90 \%$ & $46,40 \%$ & $47,00 \%$ & $44,00 \%$ & $62,30 \%$ & $61,20 \%$ & $59,50 \%$ & $59,30 \%$ & $41,80 \%$ \\
\hline & $\begin{array}{l}\text { harmonic } \\
\text { mean }\end{array}$ & $51,00 \%$ & $51,90 \%$ & $53,10 \%$ & $53,00 \%$ & $47,90 \%$ & $47,30 \%$ & $47,70 \%$ & $46,20 \%$ & $64,80 \%$ & $64,30 \%$ & $63,00 \%$ & $62,70 \%$ & $41,30 \%$ \\
\hline & $\begin{array}{l}\text { arithmetic } \\
\text { mean }\end{array}$ & $42,50 \%$ & $41,70 \%$ & $40,80 \%$ & $44,30 \%$ & $33,50 \%$ & $30,40 \%$ & $28,90 \%$ & $30,80 \%$ & $53,90 \%$ & $52,50 \%$ & $52,50 \%$ & $54,00 \%$ & $46,40 \%$ \\
\hline \multirow[t]{3}{*}{2007} & median & $34,20 \%$ & $33,70 \%$ & $35,00 \%$ & $35,40 \%$ & $30,10 \%$ & $30,40 \%$ & $27,90 \%$ & $27,50 \%$ & $47,60 \%$ & $48,00 \%$ & $48,00 \%$ & $47,60 \%$ & $39,20 \%$ \\
\hline & $\begin{array}{l}\text { harmonic } \\
\text { mean }\end{array}$ & $34,80 \%$ & $34,10 \%$ & $33,20 \%$ & $33,90 \%$ & $30,50 \%$ & $29,70 \%$ & $27,80 \%$ & $26,20 \%$ & $49,30 \%$ & $48,10 \%$ & $47,70 \%$ & $47,60 \%$ & $39,00 \%$ \\
\hline & $\begin{array}{l}\text { arithmetic } \\
\text { mean }\end{array}$ & $34,40 \%$ & $34,20 \%$ & $35,00 \%$ & $35,10 \%$ & $29,20 \%$ & $26,10 \%$ & $26,00 \%$ & $26,10 \%$ & $50,90 \%$ & $50,20 \%$ & $48,90 \%$ & $47,50 \%$ & $45,80 \%$ \\
\hline \multirow[t]{3}{*}{2006} & median & $30,50 \%$ & $29,10 \%$ & $28,30 \%$ & $29,20 \%$ & $27,50 \%$ & $25,00 \%$ & $24,70 \%$ & $25,30 \%$ & $44,70 \%$ & $44,30 \%$ & $43,60 \%$ & $43,30 \%$ & $39,50 \%$ \\
\hline & $\begin{array}{l}\text { harmonic } \\
\text { mean }\end{array}$ & $30,50 \%$ & $29,00 \%$ & $29,10 \%$ & $30,20 \%$ & $27,00 \%$ & $25,40 \%$ & $25,20 \%$ & $24,90 \%$ & $45,40 \%$ & $45,20 \%$ & $43,90 \%$ & $43,20 \%$ & $39,90 \%$ \\
\hline & $\begin{array}{l}\text { arithmetic } \\
\text { mean }\end{array}$ & $39,20 \%$ & $35,40 \%$ & $33,50 \%$ & $37,40 \%$ & $31,10 \%$ & $29,40 \%$ & $27,80 \%$ & $28,30 \%$ & $54,50 \%$ & $54,40 \%$ & $53,50 \%$ & $51,30 \%$ & $47,00 \%$ \\
\hline \multirow[t]{3}{*}{2005} & median & $31,50 \%$ & $31,30 \%$ & $28,60 \%$ & $30,60 \%$ & $27,10 \%$ & $25,10 \%$ & $25,30 \%$ & $27,00 \%$ & $50,10 \%$ & $48,30 \%$ & $47,30 \%$ & $45,70 \%$ & $38,20 \%$ \\
\hline & $\begin{array}{l}\text { harmonic } \\
\text { mean }\end{array}$ & $31,60 \%$ & $31,20 \%$ & $29,90 \%$ & $30,50 \%$ & $26,60 \%$ & $25,10 \%$ & $24,60 \%$ & $25,30 \%$ & $49,10 \%$ & $47,60 \%$ & $47,40 \%$ & $48,00 \%$ & $39,10 \%$ \\
\hline & $\begin{array}{l}\text { arithmetic } \\
\text { mean }\end{array}$ & $43,80 \%$ & $41,80 \%$ & $39,80 \%$ & $39,50 \%$ & $33,40 \%$ & $32,60 \%$ & $30,10 \%$ & $29,00 \%$ & $56,30 \%$ & $53,70 \%$ & $52,90 \%$ & $52,10 \%$ & $49,10 \%$ \\
\hline \multirow[t]{3}{*}{2004} & median & $36,50 \%$ & $35,60 \%$ & $33,50 \%$ & $33,60 \%$ & $30,80 \%$ & $29,80 \%$ & $28,40 \%$ & $29,20 \%$ & $48,80 \%$ & $48,20 \%$ & $48,00 \%$ & $48,50 \%$ & $39,30 \%$ \\
\hline & $\begin{array}{l}\text { harmonic } \\
\text { mean }\end{array}$ & $35,90 \%$ & $34,70 \%$ & $32,10 \%$ & $34,10 \%$ & $31,00 \%$ & $29,30 \%$ & $28,20 \%$ & $29,30 \%$ & $49,80 \%$ & $49,90 \%$ & $50,50 \%$ & $51,20 \%$ & $39,00 \%$ \\
\hline & $\begin{array}{l}\text { arithmetic } \\
\text { mean }\end{array}$ & $51,50 \%$ & $54,80 \%$ & $54,40 \%$ & $66,00 \%$ & $42,50 \%$ & $41,20 \%$ & $38,70 \%$ & $37,50 \%$ & $63,40 \%$ & $62,70 \%$ & $62,10 \%$ & $61,00 \%$ & $52,10 \%$ \\
\hline \multirow[t]{2}{*}{2003} & median & $47,20 \%$ & $46,00 \%$ & $44,80 \%$ & $47,70 \%$ & $40,80 \%$ & $40,00 \%$ & $38,00 \%$ & $36,60 \%$ & $59,30 \%$ & $58,50 \%$ & $57,50 \%$ & $56,30 \%$ & $41,90 \%$ \\
\hline & $\begin{array}{l}\text { harmonic } \\
\text { mean }\end{array}$ & $46,20 \%$ & $46,20 \%$ & $44,40 \%$ & $46,60 \%$ & $40,70 \%$ & $40,10 \%$ & $37,90 \%$ & $36,40 \%$ & $59,10 \%$ & $58,90 \%$ & $59,10 \%$ & $57,60 \%$ & $40,60 \%$ \\
\hline
\end{tabular}


Table 6. Enterprise Value/Sales - Enterprise Value/Invested Capital; Median Absolute Percentage Error in each year $2003-2012$ through regression analysis

\begin{tabular}{|c|c|c|c|c|c|c|}
\hline & & \multicolumn{4}{|c|}{ Core Enterprise Value / Sales } & \multirow[b]{2}{*}{$\begin{array}{c}\text { Core EV / } \\
\text { Invested } \\
\text { Capital }\end{array}$} \\
\hline & & $\begin{array}{c}\text { four years } \\
\text { Sales } \\
\text { average }\end{array}$ & $\begin{array}{c}\text { three years } \\
\text { Sales } \\
\text { average }\end{array}$ & $\begin{array}{c}\text { two years } \\
\text { Sales } \\
\text { average }\end{array}$ & Current & \\
\hline \multirow{2}{*}{2012} & Ebit margin for EV/S and EBIT/IC for EV/IC & $35,80 \%$ & $34,50 \%$ & $31,90 \%$ & $34,00 \%$ & $26,30 \%$ \\
\hline & Ebitda margin for EV/S and EBITDA/IC for EV/IC & $34,70 \%$ & $33,30 \%$ & $32,00 \%$ & $32,50 \%$ & $29,30 \%$ \\
\hline \multirow{2}{*}{2011} & Ebit margin for $\mathrm{EV} / \mathrm{S}$ and $\mathrm{EBIT} / \mathrm{IC}$ for $\mathrm{EV} / \mathrm{IC}$ & $35,60 \%$ & $36,60 \%$ & $37,00 \%$ & $36,50 \%$ & $27,60 \%$ \\
\hline & Ebitda margin for EV/S and EBITDA/IC for EV/IC & $35,10 \%$ & $34,20 \%$ & $32,80 \%$ & $33,50 \%$ & $29,60 \%$ \\
\hline \multirow{2}{*}{2010} & Ebit margin for EV/S and EBIT/IC for EV/IC & $33,40 \%$ & $33,40 \%$ & $35,70 \%$ & $33,40 \%$ & $29,90 \%$ \\
\hline & Ebitda margin for EV/S and EBITDA/IC for EV/IC & $32,20 \%$ & $32,70 \%$ & $32,80 \%$ & $29,60 \%$ & $30,30 \%$ \\
\hline \multirow{2}{*}{2009} & Ebit margin for EV/S and EBIT/IC for EV/IC & $36,90 \%$ & $36,70 \%$ & $34,90 \%$ & $39,40 \%$ & $30,20 \%$ \\
\hline & Ebitda margin for EV/S and EBITDA/IC for EV/IC & $34,00 \%$ & $31,90 \%$ & $31,50 \%$ & $31,50 \%$ & $28,70 \%$ \\
\hline \multirow{2}{*}{2008} & Ebit margin for $\mathrm{EV} / \mathrm{S}$ and $\mathrm{EBIT} / \mathrm{IC}$ for $\mathrm{EV} / \mathrm{IC}$ & $52,80 \%$ & $55,90 \%$ & $54,50 \%$ & $53,40 \%$ & $36,00 \%$ \\
\hline & Ebitda margin for EV/S and EBITDA/IC for EV/IC & $46,40 \%$ & $49,10 \%$ & $47,80 \%$ & $45,50 \%$ & $36,80 \%$ \\
\hline \multirow{2}{*}{2007} & Ebit margin for $\mathrm{EV} / \mathrm{S}$ and $\mathrm{EBIT} / \mathrm{IC}$ for $\mathrm{EV} / \mathrm{IC}$ & $35,30 \%$ & $34,40 \%$ & $34,10 \%$ & $34,30 \%$ & $26,60 \%$ \\
\hline & Ebitda margin for EV/S and EBITDA/IC for EV/IC & $34,10 \%$ & $30,90 \%$ & $29,60 \%$ & $29,70 \%$ & $27,80 \%$ \\
\hline \multirow{2}{*}{2006} & Ebit margin for $\mathrm{EV} / \mathrm{S}$ and $\mathrm{EBIT} / \mathrm{IC}$ for $\mathrm{EV} / \mathrm{IC}$ & $31,60 \%$ & $29,40 \%$ & $27,30 \%$ & $28,50 \%$ & $23,20 \%$ \\
\hline & Ebitda margin for EV/S and EBITDA/IC for EV/IC & $28,50 \%$ & $25,90 \%$ & $26,30 \%$ & $25,70 \%$ & $24,10 \%$ \\
\hline \multirow{2}{*}{2005} & Ebit margin for $\mathrm{EV} / \mathrm{S}$ and $\mathrm{EBIT} / \mathrm{IC}$ for $\mathrm{EV} / \mathrm{IC}$ & $35,00 \%$ & $32,60 \%$ & $30,30 \%$ & $29,50 \%$ & $23,70 \%$ \\
\hline & Ebitda margin for EV/S and EBITDA/IC for EV/IC & $31,40 \%$ & $28,90 \%$ & $27,40 \%$ & $27,40 \%$ & $24,80 \%$ \\
\hline \multirow{2}{*}{2004} & Ebit margin for EV/S and EBIT/IC for EV/IC & $37,70 \%$ & $33,70 \%$ & $33,00 \%$ & $33,30 \%$ & $26,20 \%$ \\
\hline & Ebitda margin for EV/S and EBITDA/IC for EV/IC & $34,70 \%$ & $31,80 \%$ & $29,80 \%$ & $29,20 \%$ & $27,90 \%$ \\
\hline \multirow{2}{*}{2003} & Ebit margin for $\mathrm{EV} / \mathrm{S}$ and $\mathrm{EBIT} / \mathrm{IC}$ for $\mathrm{EV} / \mathrm{IC}$ & $46,60 \%$ & $47,80 \%$ & $45,60 \%$ & $45,40 \%$ & $32,30 \%$ \\
\hline & Ebitda margin for EV/S and EBITDA/IC for EV/IC & $45,00 \%$ & $44,10 \%$ & $41,80 \%$ & $38,20 \%$ & $33,50 \%$ \\
\hline
\end{tabular}

Table 7. Results by sector; average Median Absolute Percentage Error for all years

\begin{tabular}{|c|c|c|c|c|c|}
\hline EV/EBIT & $\begin{array}{l}\text { four years } \\
\text { Ebit } \\
\text { average }\end{array}$ & $\begin{array}{l}\text { three } \\
\text { years Ebit } \\
\text { average }\end{array}$ & $\begin{array}{l}\text { two years } \\
\text { Ebit } \\
\text { average }\end{array}$ & Current & \\
\hline Arithmetic mean & $46,10 \%$ & $48,40 \%$ & $48,70 \%$ & $55,00 \%$ & \\
\hline Median & $43,10 \%$ & $44,10 \%$ & $46,50 \%$ & $45,90 \%$ & \\
\hline Harmonic mean & $44,10 \%$ & $45,30 \%$ & $46,40 \%$ & $46,60 \%$ & \\
\hline EV/EBITDA & $\begin{array}{c}\text { four years } \\
\text { Ebitda } \\
\text { average }\end{array}$ & $\begin{array}{c}\text { three years } \\
\text { Ebitda } \\
\text { average }\end{array}$ & $\begin{array}{c}\text { two years } \\
\text { Ebitda } \\
\text { average }\end{array}$ & Current & \\
\hline Arithmetic mean & $40,40 \%$ & $37,90 \%$ & $36,90 \%$ & $35,00 \%$ & \\
\hline Median & $33,40 \%$ & $35,30 \%$ & $35,30 \%$ & $31,90 \%$ & \\
\hline Harmonic mean & $35,40 \%$ & $36,10 \%$ & $33,80 \%$ & $33,10 \%$ & \\
\hline EV/SALES & $\begin{array}{c}\text { four years } \\
\text { Sales } \\
\text { average }\end{array}$ & $\begin{array}{c}\text { three years } \\
\text { Sales } \\
\text { average }\end{array}$ & $\begin{array}{c}\text { two years } \\
\text { Sales } \\
\text { average }\end{array}$ & Current & $E V / I C$ \\
\hline Arithmetic mean & $55,50 \%$ & $53,70 \%$ & $52,00 \%$ & $48,10 \%$ & $47,50 \%$ \\
\hline Median & $50,40 \%$ & $47,90 \%$ & $45,40 \%$ & $45,20 \%$ & $39,30 \%$ \\
\hline Harmonic mean & $46,40 \%$ & $47,20 \%$ & $45,60 \%$ & $44,50 \%$ & $40,70 \%$ \\
\hline Regression with EBIT Margin - Ebit / IC & $40,30 \%$ & $42,80 \%$ & $41,90 \%$ & $43,80 \%$ & $29,10 \%$ \\
\hline Regression with EBITDA Margin Ebitda / IC & $40,60 \%$ & $38,30 \%$ & $36,30 \%$ & $36,60 \%$ & $32,90 \%$ \\
\hline
\end{tabular}


Basic Materials

\begin{tabular}{|c|c|c|c|c|c|}
\hline EV/EBIT & $\begin{array}{l}\text { four years } \\
\text { Ebit } \\
\text { average }\end{array}$ & $\begin{array}{l}\text { three } \\
\text { years Ebit } \\
\text { average }\end{array}$ & $\begin{array}{l}\text { two years } \\
\text { Ebit } \\
\text { average }\end{array}$ & Current & \\
\hline Arithmetic mean & $44,00 \%$ & $53,10 \%$ & $55,10 \%$ & $70,10 \%$ & \\
\hline Median & $39,60 \%$ & $41,80 \%$ & $45,60 \%$ & $53,50 \%$ & \\
\hline Harmonic mean & $39,40 \%$ & $41,50 \%$ & $45,20 \%$ & $51,20 \%$ & \\
\hline EV/EBITDA & $\begin{array}{c}\text { four years } \\
\text { Ebitda } \\
\text { average }\end{array}$ & $\begin{array}{c}\text { three years } \\
\text { Ebitda } \\
\text { average }\end{array}$ & $\begin{array}{c}\text { two years } \\
\text { Ebitda } \\
\text { average }\end{array}$ & Current & \\
\hline Arithmetic mean & $34,70 \%$ & $35,00 \%$ & $33,60 \%$ & $35,40 \%$ & \\
\hline Median & $32,70 \%$ & $33,30 \%$ & $31,10 \%$ & $33,40 \%$ & \\
\hline Harmonic mean & $33,10 \%$ & $33,50 \%$ & $33,60 \%$ & $35,20 \%$ & \\
\hline EV/SALES & $\begin{array}{c}\text { four years } \\
\text { Sales } \\
\text { average }\end{array}$ & $\begin{array}{c}\text { three years } \\
\text { Sales } \\
\text { average }\end{array}$ & $\begin{array}{c}\text { two years } \\
\text { Sales } \\
\text { average }\end{array}$ & Current & $\mathrm{EV} / \mathrm{IC}$ \\
\hline Arithmetic mean & $77,80 \%$ & $73,10 \%$ & $68,20 \%$ & $64,40 \%$ & $40,60 \%$ \\
\hline Median & $48,10 \%$ & $48,50 \%$ & $48,20 \%$ & $49,20 \%$ & $35,90 \%$ \\
\hline Harmonic mean & $50,50 \%$ & $49,30 \%$ & $48,90 \%$ & $49,60 \%$ & $35,90 \%$ \\
\hline Regression with EBIT Margin - Ebit / IC & $32,10 \%$ & $34,00 \%$ & $36,70 \%$ & $37,30 \%$ & $25,80 \%$ \\
\hline Regression with EBITDA Margin Ebitda / IC & $37,60 \%$ & $35,40 \%$ & $33,30 \%$ & $33,30 \%$ & $26,40 \%$ \\
\hline \multicolumn{6}{|l|}{ Chemicals } \\
\hline EV/EBIT & $\begin{array}{l}\text { four years } \\
\text { Ebit } \\
\text { average } \\
\end{array}$ & $\begin{array}{l}\text { three } \\
\text { years Ebit } \\
\text { average } \\
\end{array}$ & $\begin{array}{l}\text { two years } \\
\text { Ebit } \\
\text { average }\end{array}$ & Current & \\
\hline Arithmetic mean & $37,30 \%$ & $39,30 \%$ & $39,10 \%$ & $48,70 \%$ & \\
\hline Median & $33,20 \%$ & $32,40 \%$ & $34,60 \%$ & $33,70 \%$ & \\
\hline Harmonic mean & $33,90 \%$ & $33,40 \%$ & $34,10 \%$ & $33,40 \%$ & \\
\hline EV/EBITDA & $\begin{array}{c}\text { four years } \\
\text { Ebitda } \\
\text { average } \\
\end{array}$ & $\begin{array}{c}\text { three years } \\
\text { Ebitda } \\
\text { average }\end{array}$ & $\begin{array}{c}\text { two years } \\
\text { Ebitda } \\
\text { average }\end{array}$ & Current & \\
\hline Arithmetic mean & $30,70 \%$ & $30,30 \%$ & $29,30 \%$ & $30,50 \%$ & \\
\hline Median & $30,30 \%$ & $29,70 \%$ & $29,50 \%$ & $28,30 \%$ & \\
\hline Harmonic mean & $31,40 \%$ & $31,00 \%$ & $30,60 \%$ & $29,10 \%$ & \\
\hline EV/SALES & $\begin{array}{c}\text { four years } \\
\text { Sales } \\
\text { average } \\
\end{array}$ & $\begin{array}{c}\text { three years } \\
\text { Sales } \\
\text { average }\end{array}$ & $\begin{array}{c}\text { two years } \\
\text { Sales } \\
\text { average } \\
\end{array}$ & Current & $\mathrm{EV} / \mathrm{IC}$ \\
\hline Arithmetic mean & $54,60 \%$ & $52,50 \%$ & $51,00 \%$ & $50,20 \%$ & $37,20 \%$ \\
\hline Median & $45,50 \%$ & $43,30 \%$ & $42,70 \%$ & $41,50 \%$ & $35,70 \%$ \\
\hline Harmonic mean & $44,40 \%$ & $43,00 \%$ & $43,10 \%$ & $40,50 \%$ & $35,50 \%$ \\
\hline Regression with EBIT Margin - Ebit / IC & $31,90 \%$ & $31,20 \%$ & $31,00 \%$ & $32,30 \%$ & $26,30 \%$ \\
\hline Regression with EBITDA Margin Ebitda / IC & $31,70 \%$ & $32,10 \%$ & $30,50 \%$ & $29,60 \%$ & $28,40 \%$ \\
\hline
\end{tabular}




\begin{tabular}{|c|c|c|c|c|c|}
\hline \multirow[b]{2}{*}{ EV/EBIT } & \multirow{2}{*}{$\begin{array}{l}\text { four years } \\
\text { Ebit } \\
\text { average }\end{array}$} & \multirow{2}{*}{$\begin{array}{l}\text { three } \\
\text { years Ebit } \\
\text { average }\end{array}$} & \multicolumn{2}{|l|}{ two years } & \\
\hline & & & $\begin{array}{l}\text { Ebit } \\
\text { average }\end{array}$ & Current & \\
\hline Arithmetic mean & $45,40 \%$ & $44,50 \%$ & $46,10 \%$ & $52,70 \%$ & \\
\hline Median & $38,50 \%$ & $38,10 \%$ & $36,80 \%$ & $40,50 \%$ & \\
\hline Harmonic mean & $36,70 \%$ & $36,80 \%$ & $36,30 \%$ & $40,10 \%$ & \\
\hline EV/EBITDA & $\begin{array}{c}\text { four years } \\
\text { Ebitda } \\
\text { average }\end{array}$ & $\begin{array}{c}\text { three years } \\
\text { Ebitda } \\
\text { average }\end{array}$ & $\begin{array}{c}\text { two years } \\
\text { Ebitda } \\
\text { average }\end{array}$ & Current & \\
\hline Arithmetic mean & $36,90 \%$ & $34,30 \%$ & $33,50 \%$ & $32,70 \%$ & \\
\hline Median & $33,40 \%$ & $33,50 \%$ & $33,40 \%$ & $33,20 \%$ & \\
\hline Harmonic mean & $32,40 \%$ & $33,10 \%$ & $33,10 \%$ & $33,30 \%$ & \\
\hline EV/SALES & $\begin{array}{c}\text { four years } \\
\text { Sales } \\
\text { average }\end{array}$ & $\begin{array}{c}\text { three years } \\
\text { Sales } \\
\text { average }\end{array}$ & $\begin{array}{c}\text { two years } \\
\text { Sales } \\
\text { average }\end{array}$ & Current & $E V / I C$ \\
\hline Arithmetic mean & $55,10 \%$ & $55,40 \%$ & $55,10 \%$ & $57,30 \%$ & $44,40 \%$ \\
\hline Median & $56,60 \%$ & $55,60 \%$ & $56,40 \%$ & $56,30 \%$ & $36,90 \%$ \\
\hline Harmonic mean & $62,10 \%$ & $61,90 \%$ & $61,80 \%$ & $61,70 \%$ & $37,30 \%$ \\
\hline Regression with EBIT Margin - Ebit / IC & $40,90 \%$ & $41,30 \%$ & $41,30 \%$ & $42,40 \%$ & $29,10 \%$ \\
\hline Regression with EBITDA Margin Ebitda / IC & $37,10 \%$ & $35,20 \%$ & $35,30 \%$ & $33,40 \%$ & $28,90 \%$ \\
\hline \multicolumn{6}{|l|}{ Cyclical Goods } \\
\hline EV/EBIT & $\begin{array}{l}\text { four years } \\
\text { Ebit } \\
\text { average }\end{array}$ & $\begin{array}{l}\text { three } \\
\text { years Ebit } \\
\text { average }\end{array}$ & $\begin{array}{l}\text { two years } \\
\text { Ebit } \\
\text { average }\end{array}$ & Current & \\
\hline Arithmetic mean & $52,50 \%$ & $50,30 \%$ & $50,60 \%$ & $57,80 \%$ & \\
\hline Median & $43,20 \%$ & $41,00 \%$ & $39,10 \%$ & $39,20 \%$ & \\
\hline Harmonic mean & $40,30 \%$ & $39,50 \%$ & $39,10 \%$ & $38,10 \%$ & \\
\hline EV/EBITDA & $\begin{array}{c}\text { four years } \\
\text { Ebitda } \\
\text { average }\end{array}$ & $\begin{array}{c}\text { three years } \\
\text { Ebitda } \\
\text { average } \\
\end{array}$ & $\begin{array}{c}\text { two years } \\
\text { Ebitda } \\
\text { average }\end{array}$ & Current & \\
\hline Arithmetic mean & $39,30 \%$ & $37,90 \%$ & $37,90 \%$ & $35,70 \%$ & \\
\hline Median & $35,80 \%$ & $34,60 \%$ & $34,20 \%$ & $33,60 \%$ & \\
\hline Harmonic mean & $36,10 \%$ & $35,40 \%$ & $34,00 \%$ & $33,30 \%$ & \\
\hline EV/SALES & $\begin{array}{c}\text { four years } \\
\text { Sales } \\
\text { average } \\
\end{array}$ & $\begin{array}{c}\text { three years } \\
\text { Sales } \\
\text { average } \\
\end{array}$ & $\begin{array}{c}\text { two years } \\
\text { Sales } \\
\text { average } \\
\end{array}$ & Current & $\mathrm{EV} / \mathrm{IC}$ \\
\hline Arithmetic mean & $65,30 \%$ & $63,50 \%$ & $63,50 \%$ & $63,30 \%$ & $55,30 \%$ \\
\hline Median & $59,80 \%$ & $60,10 \%$ & $59,90 \%$ & $58,90 \%$ & $46,90 \%$ \\
\hline Harmonic mean & $55,60 \%$ & $55,40 \%$ & $55,70 \%$ & $55,40 \%$ & $46,00 \%$ \\
\hline Regression with EBIT Margin - Ebit / IC & $46,70 \%$ & $44,40 \%$ & $42,10 \%$ & $41,40 \%$ & $31,40 \%$ \\
\hline Regression with EBITDA Margin Ebitda / IC & $39,70 \%$ & $38,40 \%$ & $37,50 \%$ & $35,00 \%$ & $32,50 \%$ \\
\hline
\end{tabular}


Industrial

\begin{tabular}{|c|c|c|c|c|c|}
\hline EV/EBIT & $\begin{array}{l}\text { four years } \\
\text { Ebit } \\
\text { average }\end{array}$ & $\begin{array}{l}\text { three } \\
\text { years Ebit } \\
\text { average }\end{array}$ & $\begin{array}{l}\text { two years } \\
\text { Ebit } \\
\text { average }\end{array}$ & Current & \\
\hline Arithmetic mean & $39,00 \%$ & $39,00 \%$ & $38,20 \%$ & $41,80 \%$ & \\
\hline Median & $34,60 \%$ & $34,20 \%$ & $32,90 \%$ & $33,70 \%$ & \\
\hline Harmonic mean & $34,50 \%$ & $33,50 \%$ & $32,10 \%$ & $32,90 \%$ & \\
\hline EV/EBITDA & $\begin{array}{c}\text { four years } \\
\text { Ebitda } \\
\text { average }\end{array}$ & $\begin{array}{c}\text { three years } \\
\text { Ebitda } \\
\text { average }\end{array}$ & $\begin{array}{c}\text { two years } \\
\text { Ebitda } \\
\text { average }\end{array}$ & Current & \\
\hline Arithmetic mean & $33,10 \%$ & $31,90 \%$ & $30,70 \%$ & $30,80 \%$ & \\
\hline Median & $31,80 \%$ & $30,90 \%$ & $29,70 \%$ & $29,40 \%$ & \\
\hline Harmonic mean & $31,80 \%$ & $30,50 \%$ & $29,80 \%$ & $29,10 \%$ & \\
\hline EV/SALES & $\begin{array}{c}\text { four years } \\
\text { Sales } \\
\text { average }\end{array}$ & $\begin{array}{c}\text { three years } \\
\text { Sales } \\
\text { average } \\
\end{array}$ & $\begin{array}{c}\text { two years } \\
\text { Sales } \\
\text { average }\end{array}$ & Current & $E V / I C$ \\
\hline Arithmetic mean & $55,90 \%$ & $55,60 \%$ & $55,70 \%$ & $54,60 \%$ & $46,90 \%$ \\
\hline Median & $51,40 \%$ & $50,80 \%$ & $50,50 \%$ & $49,90 \%$ & $39,60 \%$ \\
\hline Harmonic mean & $51,70 \%$ & $50,90 \%$ & $50,50 \%$ & $50,60 \%$ & $39,30 \%$ \\
\hline Regression with EBIT Margin - Ebit / IC & $35,60 \%$ & $34,90 \%$ & $33,70 \%$ & $33,60 \%$ & $26,20 \%$ \\
\hline Regression with EBITDA Margin Ebitda / IC & $33,40 \%$ & $32,10 \%$ & $31,30 \%$ & $30,90 \%$ & $27,80 \%$ \\
\hline \multicolumn{6}{|l|}{ Media } \\
\hline EV/EBIT & $\begin{array}{l}\text { four years } \\
\text { Ebit } \\
\text { average }\end{array}$ & $\begin{array}{l}\text { three } \\
\text { years Ebit } \\
\text { average }\end{array}$ & $\begin{array}{l}\text { two years } \\
\text { Ebit } \\
\text { average }\end{array}$ & Current & \\
\hline Arithmetic mean & $39,90 \%$ & $39,50 \%$ & $41,70 \%$ & $42,70 \%$ & \\
\hline Median & $35,90 \%$ & $34,90 \%$ & $34,80 \%$ & $37,80 \%$ & \\
\hline Harmonic mean & $34,90 \%$ & $35,40 \%$ & $34,70 \%$ & $36,40 \%$ & \\
\hline EV/EBITDA & $\begin{array}{c}\text { four years } \\
\text { Ebitda } \\
\text { average }\end{array}$ & $\begin{array}{c}\text { three years } \\
\text { Ebitda } \\
\text { average } \\
\end{array}$ & $\begin{array}{c}\text { two years } \\
\text { Ebitda } \\
\text { average }\end{array}$ & Current & \\
\hline Arithmetic mean & $32,10 \%$ & $31,10 \%$ & $29,80 \%$ & $30,50 \%$ & \\
\hline Median & $31,40 \%$ & $30,00 \%$ & $29,20 \%$ & $30,20 \%$ & \\
\hline Harmonic mean & $31,60 \%$ & $30,50 \%$ & $30,20 \%$ & $30,40 \%$ & \\
\hline EV/SALES & $\begin{array}{c}\text { four years } \\
\text { Sales } \\
\text { average } \\
\end{array}$ & $\begin{array}{c}\text { three years } \\
\text { Sales } \\
\text { average }\end{array}$ & $\begin{array}{c}\text { two years } \\
\text { Sales } \\
\text { average } \\
\end{array}$ & Current & $E V / I C$ \\
\hline Arithmetic mean & $49,30 \%$ & $48,80 \%$ & $48,80 \%$ & $48,10 \%$ & $47,60 \%$ \\
\hline Median & $48,50 \%$ & $47,50 \%$ & $46,40 \%$ & $48,20 \%$ & $40,90 \%$ \\
\hline Harmonic mean & $50,30 \%$ & $50,10 \%$ & $50,00 \%$ & $48,70 \%$ & $39,30 \%$ \\
\hline Regression with EBIT Margin - Ebit / IC & $36,10 \%$ & $35,30 \%$ & $34,00 \%$ & $35,30 \%$ & $28,70 \%$ \\
\hline Regression with EBITDA Margin Ebitda / IC & $33,40 \%$ & $32,10 \%$ & $30,40 \%$ & $30,40 \%$ & $28,00 \%$ \\
\hline
\end{tabular}




\begin{tabular}{|c|c|c|c|c|c|}
\hline EV/EBIT & $\begin{array}{l}\text { four years } \\
\text { Ebit } \\
\text { average }\end{array}$ & $\begin{array}{l}\text { three } \\
\text { years Ebit } \\
\text { average }\end{array}$ & $\begin{array}{l}\text { two years } \\
\text { Ebit } \\
\text { average }\end{array}$ & Current & \\
\hline Arithmetic mean & $47,70 \%$ & $46,30 \%$ & $45,40 \%$ & $46,70 \%$ & \\
\hline Median & $36,60 \%$ & $35,40 \%$ & $34,50 \%$ & $34,40 \%$ & \\
\hline Harmonic mean & $37,60 \%$ & $36,00 \%$ & $34,80 \%$ & $34,00 \%$ & \\
\hline EV/EBITDA & $\begin{array}{c}\text { four years } \\
\text { Ebitda } \\
\text { average }\end{array}$ & $\begin{array}{c}\text { three years } \\
\text { Ebitda } \\
\text { average }\end{array}$ & $\begin{array}{c}\text { two years } \\
\text { Ebitda } \\
\text { average } \\
\end{array}$ & Current & \\
\hline Arithmetic mean & $37,10 \%$ & $35,10 \%$ & $34,30 \%$ & $34,00 \%$ & \\
\hline Median & $35,70 \%$ & $33,50 \%$ & $31,10 \%$ & $29,90 \%$ & \\
\hline Harmonic mean & $35,30 \%$ & $33,40 \%$ & $29,70 \%$ & $30,00 \%$ & \\
\hline EV/SALES & $\begin{array}{c}\text { four years } \\
\text { Sales } \\
\text { average } \\
\end{array}$ & $\begin{array}{c}\text { three years } \\
\text { Sales } \\
\text { average } \\
\end{array}$ & $\begin{array}{c}\text { two years } \\
\text { Sales } \\
\text { average } \\
\end{array}$ & Current & $E V / I C$ \\
\hline Arithmetic mean & $61,50 \%$ & $60,60 \%$ & $61,90 \%$ & $61,90 \%$ & $70,00 \%$ \\
\hline Median & $56,30 \%$ & $55,60 \%$ & $55,30 \%$ & $55,00 \%$ & $45,00 \%$ \\
\hline Harmonic mean & $54,90 \%$ & $56,10 \%$ & $56,80 \%$ & $57,70 \%$ & $45,60 \%$ \\
\hline Regression with EBIT Margin - Ebit / IC & $36,70 \%$ & $35,60 \%$ & $32,90 \%$ & $34,20 \%$ & $34,00 \%$ \\
\hline Regression with EBITDA Margin Ebitda / IC & $36,20 \%$ & $35,40 \%$ & $32,60 \%$ & $32,20 \%$ & $33,80 \%$ \\
\hline
\end{tabular}

Table 8. Economic Significance of Performed Regressions (average $\mathrm{R}^{2}$ )

\begin{tabular}{|c|c|c|c|c|c|}
\hline & $\begin{array}{l}\text { EV/Sales }{ }_{4 \gamma^{*}}=\alpha+\beta \\
x \text { Ebitda-Margin }\end{array}$ & 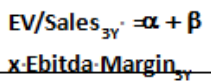 & $\begin{array}{l}\text { EV/Sales } 2_{y^{*}}=\alpha+\beta \\
x \cdot \text { Ebitda-Margin }\end{array}$ & $\begin{array}{l}\text { EV/Sales1 }{ }_{Y^{*}}=\alpha+\beta \\
x \cdot \text { Ebitda-Margin }\end{array}$ & $\begin{array}{l}\mathrm{EV} / \mathrm{IC}=\alpha+\beta \cdot \mathrm{x} \\
\text { Ebitda/IC }\end{array}$ \\
\hline Average-All-Sectors & $48,8 \%$ & $50,8 \%$ & $52,2 \%$ & $51,9 \%$ & $44,7 \%$ \\
\hline Auto & $37,6 \%$ & $38,6 \%$ & $37,1 \%$ & $39,4 \%$ & $35,3 \%$ \\
\hline Basic-Materials & $52,4 \%$ & $54,8 \%$ & $52,9 \%$ & $48,1 \%$ & $39,0 \%$ \\
\hline Chemicals & $47,3 \%$ & $51,0 \%$ & $51,9 \%$ & $49,3 \%$ & $34,3 \%$ \\
\hline Construction & $52,9 \%$ & $56,2 \%$ & $59,2 \%$ & $56,5 \%$ & $42,8 \%$ \\
\hline Cyclical-Goods & $46,8 \%$ & $49,1 \%$ & $51,7 \%$ & $53,2 \%$ & $49,8 \%$ \\
\hline Industrial & $51,8 \%$ & $53,7 \%$ & $54,5 \%$ & $54,9 \%$ & $48,2 \%$ \\
\hline Media & $46,8 \%$ & $49,1 \%$ & $50,7 \%$ & $54,0 \%$ & $46,4 \%$ \\
\hline \multirow[t]{2}{*}{ Retail } & $56,0 \%$ & $55,8 \%$ & $61,4 \%$ & $61,4 \%$ & $61,4 \%$ \\
\hline & $\begin{array}{l}\text { EV/Sales }_{4 Y^{*}}=\alpha+\beta \\
x \cdot \text { Ebit-Margin } \\
41\end{array}$ & $\begin{array}{l}\text { EV/Sales }_{3 y^{*}}=\alpha+\beta \\
x \text {-Ebit-Margin, }\end{array}$ & $\begin{array}{l}\text { EV/Sales2 } \gamma_{\gamma^{\prime}}=\alpha+\beta \\
x \text {-Ebit-Margin }\end{array}$ & $\begin{array}{l}\text { EV/Sales1 }{ }_{Y^{*}}=\alpha+\beta \\
x \cdot \text { Ebit-Margin }\end{array}$ & $\begin{array}{l}\mathrm{EV} / \mathrm{IC}=\boldsymbol{\alpha}+\boldsymbol{\beta} \cdot \mathrm{x} \\
\text { Ebit/IC }\end{array}$ \\
\hline Average-All-Sectors & $46,0 \%$ & $45,8 \%$ & $46,3 \%$ & $43,1 \%$ & $46,7 \%$ \\
\hline Auto & $43,7 \%$ & $40,6 \%$ & $37,4 \%$ & $30,5 \%$ & $41,6 \%$ \\
\hline Basic-Materials & $54,2 \%$ & $54,0 \%$ & $50,4 \%$ & $43,2 \%$ & $48,9 \%$ \\
\hline Chemicals & $49,1 \%$ & $47,7 \%$ & $47,9 \%$ & $45,3 \%$ & $38,7 \%$ \\
\hline Construction & $49,5 \%$ & $51,2 \%$ & $53,6 \%$ & $49,8 \%$ & $40,2 \%$ \\
\hline Cyclical-Goods & $37,5 \%$ & $37,8 \%$ & $39,8 \%$ & $39,1 \%$ & $47,8 \%$ \\
\hline Industrial & $47,7 \%$ & $48,4 \%$ & $48,5 \%$ & $44,9 \%$ & $50,6 \%$ \\
\hline Media & $36,6 \%$ & $35,8 \%$ & $35,5 \%$ & $35,5 \%$ & $46,1 \%$ \\
\hline Retail & $50.7 \%$ & $52.3 \%$ & $60.7 \%$ & $59.7 \%$ & $60.4 \%$ \\
\hline
\end{tabular}

This table shows the economic significance (squared r) of performed regressions. At the end of each year we perform the following regressions (made on a sector base):

1) Enterprise Value / Sales $=+x$ EBITDA / Sales

2) Enterprise Value $/$ Sales $=+x$ EBIT $/$ Sales

3) Enterprise Value / Invested Capital $=+x$ EBITDA / Invested Capital

4) Enterprise Value / Invested Capital $=+x$ EBIT / Invested Capital

The table shows the average $\mathrm{R}^{2}$ (2003 -. 2012) obtained for the performed regressions in each sector. 


\section{References}

Alford, A. W. (1992). 'The effect of the set of comparable firms on the accuracy of the price-earnings valuation method', Journal of Accounting Research, 30, 94-108. https://doi.org/10.2307/2491093

Beatty, R., Riffe, S., \& Thompson, R. (1999). 'The method of comparables and tax court valuations of private firms: an empirical investigation. Accounting Horizon, 13, 177-199. https://doi.org/10.2308/acch.1999.13.3.177

Bhojraj, S., \& Lee C. M. C. (2002). 'Who is my peer? A valuation-based approach to the selection of comparable firms. Journal of Accounting Research, 40, 407-439. https://doi.org/10.1111/1475-679X.00054

Cheng, C. S. A., \& McNamara, R. (2000). 'The valuation accuracy of the price earnings and price-book benchmark valuation methods'. Review of Quantitative Finance and Accounting, 15, 349-370. https://doi.org/10.1023/A:1012050524545

Damodaran, A. (2009). 'Ups and downs: valuing cyclical and commodity companies' Working Paper (Stern School of Business, New York University, 2009), available at SSRN: http://ssrn.com/abstract=1466041

Damodaran, A. (2012). 'Investment Valuation', John Wiley \& Sons, Inc., 2012. Hoboken, N.J.

De Heer, M., Koller, T., Schauten, M. B. J., \& Steenbeck, O. W. (2000). 'The valuation of cyclical companies', Working Paper.

Deng, M., Easton, P., \& Yeo, J. (2010). 'Another look at enterprise and equity valuation based on multiples', Working Paper, 2010, available at SSRN: http://ssrn.com/abstract=1462794

Dittmann, I., \& Maug, E. (2008). 'Biases and error measures: how to compare valuation methods', Working Paper, 2008, available SSRN: http://ssrn.com/abstract=947436

Dittmann, I., \& Weiner C. (2005). 'Selecting comparables for the valuation of European firms'. Discussion Paper (SFB. 2005). https://doi.org/10.2139/ssrn.644101

Harbula, P. (2009). 'Valuation multiples: accuracy and drivers - evidence from the European stock market', Business Valuation Review, 28, 186-200. https://doi.org/10.5791/0882-2875-28.4.186

Herrmann, V., \& Richter, F. (2003). 'Pricing with performance-controlled multiples'. Schmalenbach Business Review, 55, 194-219. https://doi.org/10.1007/BF03396674

Kaplan, S. N., \& Ruback, R. S. (1995). 'The valuation of cash flow forecasts: an empirical analysis'. Journal of Finance, 50, 1059-1093. https://doi.org/10.1111/j.1540-6261.1995.tb04050.x

Kaplan, S. N., \& Ruback, R. S. (1996). 'The market pricing of cash flow forecasts: discounted cash flow vs. the method of "comparables". Journal of Applied Corporate Finance, 8, 45-60. https://doi.org/10.1111/j.1745-6622.1996.tb00682.x

Kim, M., \& Ritter, J. R. (1999). 'Valuing IPOs', Journal of Financial Economics, 53, 409-437. https://doi.org/10.1016/S0304-405X(99)00027-6

Koller, T., Goedhart, M., \& Wessels D. (2012). 'Valuation. Measuring and managing the value of companies', McKinsey \& Company, John Wiley \& Sons, Inc.. Hoboken, N.J., fourth edition.

Lie, E., \& Lie, H. H. (2002). 'Multiple used to estimate corporate value' Financial Analysts Journal, 58, 44-54. https://doi.org/10.2469/faj.v58.n2.2522

Liu, J., Nissim, D., \& Thomas, J. K. (2002). 'Equity Valuation using Multiples'. Journal of Accounting Research 40, 135-172. https://doi.org/10.1111/1475-679X.00042

Liu, J., Nissim, D., \& Thomas, J. K. (2007). 'Is cash flow king in valuations?' Financial Analysts Journal, 63, 1-13. https://doi.org/10.2469/faj.v63.n2.4522

Pinto, J. E., Henry, E., Robinson, T. R., \& Stowe, J. D. (2010). 'Equity asset valuation', John Wiley \& Sons, Inc.,. Hoboken, N.J., second edition.

Pratt, S. P. (2001). 'The market approach to valuing businesses', John Wiley \& Sons, Inc., Hoboken, N.J.

Schreiner, A., \& Spremann, K. (2008). 'Multiples and their valuation accuracy in European equity markets', Working Paper, available at SSRN: http://ssrn.com/abstract=957352

Tremolizzo, D. (2009). 'Mis-valuation of cyclical companies. An empirical research, Erasmus University Rotterdam, MSc Economics and Business, Master Specialisation in Financial Economics.

\section{Copyrights}

Copyright for this article is retained by the author(s), with first publication rights granted to the journal.

This is an open-access article distributed under the terms and conditions of the Creative Commons Attribution license (http://creativecommons.org/licenses/by/4.0/). 